Nevada

Environmental

Restoration

Project
DOE/NV--515

UC-700

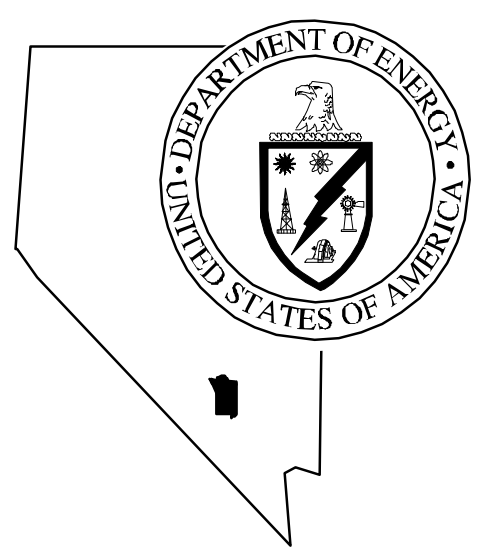

Corrective Action Investigation Plan for Corrective Action Unit 261:

Test Cell A Leachfield System,

$\mathrm{N}$ evada Test $\mathrm{S}$ ite, $\mathrm{N}$ evada

Controlled Copy $\mathrm{N} 0 .:$

Revision N 0.: 0

September 1998

Approved for public release; further distribution is authorized.

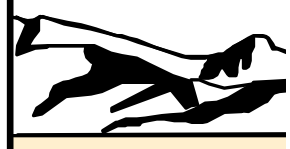

Environm ental Restoration

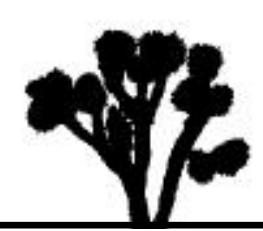

Division 
Available to the public from -

U.S. Department of Commerce

National Technical Information Service

5285 Port Royal Road

Springfield, VA 22161

(703) $487-4650$

Available electronically at http://www.doe.gov/bridge. Available to U.S. Department of Energy and its contractors in paper form -

U.S. Department of Energy

Office of Scientific and Technical Information

P.O. Box 62

Oak Ridge, TN 37831-0062

(423) 576-8401 


\section{CORRECTIVE ACTION INVESTIGATION PLAN FOR CORRECTIVE ACTION UNIT 261: TEST CELL A LEACHFIELD SYSTEM, NEVADA TEST SITE, NEVADA}

DOE Nevada Operations Office

Las Vegas, Nevada

Controlled Copy No.:

Revision No.: 0

September 1998 


\section{CORRECTIVE ACTION INVESTIGATION PLAN FOR CORRECTIVE ACTION UNIT 261: TEST CELL A LEACHFIELD SYSTEM, NEVADA TEST SITE, NEVADA}

Signature Approved

Approved by:

9/18/98

Janet Appenzeller-Wing, Project Manager

Industrial Sites Subproject

Signature Approved

$9 / 18 / 98$

Approved by:

Date:

Runore C. Wycoff, Project Manager

Nevada Environmental Restoration Project 


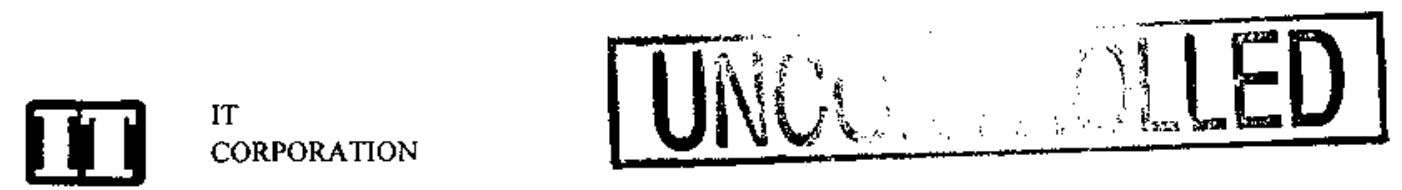

\section{RECORD OF TECHNICAL CHANGE}

Technical Change No. 1

Project/Job No. $\quad 77671132010100$

\begin{tabular}{l} 
Page $\frac{1}{1}$ of $\frac{3}{3}$ \\
Date $\quad 2 / 25 / 99$ \\
\hline
\end{tabular}

Project/Job Name Industrial Sites / CAU 26]

The following technical changes (including justification) are requested by:

Dustin Wilson

(Name)
Industrial Sites Task Manager

(Title)

The deletions, changes, and additions specified in this Record of Technical Change apply to Sections 1.0, 2.2, 3.2, 4.1, 4.2.3:4, and 7.0, and Figures 1-2, 4-1, and 4-2, of the Corrective Action Investigation Plan for Corrective Action Unit 261: Test Cell A Leachfield System, Nevada Test Site, Nevada, Rev. 0, DOE/NV--519. U.S. Department of Energy, Nevada Operations Office, September, 1998.

These deletions, changes, and additions are required because of additional site-specific historical information not discussed in the Data Quality Objective (DQO) process or addressed in the Corrective Action Investigation Plan (CAIP). The leachfield and collection system addressed by Corrective Action Unit (CAU) 261 is one of the two leachfield systems that received effluent from Building 3124 at Test Cell A in Area 25 of the Nevada Test Site. The following summary is an update of the building's operational history based on the additional information.

Building 3124 was constructed in 1962 to support the Test Cell A reactor test facility at the Nuclear Rocket Development Station (NRDS). The building was named the Equipment Testing Laboratory (ETL). During NRDS operations, the ETL contained equipment for water flow testing, gas flow testing, static pressure testing, equipment maintenance and cleaning, and limited analytical work. Building 3124 was used for various laboratories, including a high-level radioactive sample handling facility, sometime after Test Cell A was deactivated in 1966 . This facility was primarily used to support Nevada Applied Ecology Group (NAEG) sampling to examine the biological effects of plutonium and other transuranics. Activities included sample preparation and possibly some analytical work. The building was refurbished in 1991 and renamed as the Treatability Test Facility (TTF). Preparation for TTF operations included grouting the floor drains in Building 3124. The TTF was used to study radioactively contaminated soil remediation techniques for about 2.5 years. After 1995, "Waste Management" used the TTF for bench scale lead separation soil treatability tests for a short time. Building 3124 is currently unoccupied.

This summary is based on information provided in Revision 1 of the CAU 266 CAIP. No information regarding the effluent generated by activities conducted in Building 3124 after the deactivation of Test Cell A has been located. Effluent produced by laboratory operations and treatability experiments may have reached both the sanitary (CAU 266) and radioactive (CAU 261) leachfields. The historical information and list of required analytes provided in the CAU 261 must be changed based on this possibility.

The following information represents deletions, changes, and additions to the Corrective Action Investigation Plan:

\section{Section 1.0 paragraph 3 sentences 3 and 4}

Change sentences to "Operations within Building 3124 resulted in the release of potentially contaminated effluent to the leachfield and AWLP (DOE, 1988a). The surface and subsurface soils in the vicinity of the collection system, AWLP, and leachfield have potentially been impacted by radioactive and other contaminants of potential concern (COPCs) associated with Test Cell $\mathrm{A}$ equipment decontamination, laboratory operations, or contaminated soil treatability experiments. 


\section{RECORD OF TECHNICAL CHANGE}

Technical Change No. 1 Page 22 of 3

Figures 1-2, 4-1, and 4-2

Change 100 on foot scale to read 75 .

Section 2.2 paragraph 1 sentence 3

Delete sentence 3.

Section 2.2 paragraph 2

Change paragraph to "Activities conducted in Building 3124 following the deactivation of Test Cell A in 1966 are described in Section 2.2 of the CAU 266 CAIP (DOE/NV, 1999). The building was remodeled to house various laboratories including a high-level radioactive sample handling facility and later remodeled and renamed the Treatability Test Facility (TTF) to provide facilities for contaminated soil treatment experiments. It is unknown if effluent associated with these operations was introduced into the CAU 261 leachfield. The building is presently unoccupied. Brief descriptions of the two CASs addressed by CAU 261 are provided in Section 2.2.1 and Section 2.2.2, and the entire site is discussed in Section 2.2.3."

\section{Section 3.2}

Add sentence to end of paragraph I "Additional contaminants associated with operation of radiological laboratories may be present."

Add the following bullets to the first bullet list:

- Total petroleum hydrocarbons (TPH)

- Polychlorinated biphenyls (PCBs)

Add the following bullets to the second bullet list:

- TPH (oil/diesel-range organics)

- PCBs

- Isotopic Uranium (minimum 25 percent of samples)

- Isotopic Plutonium (minimum 25 percent of samples)

- Isotopic Americium (minimum 25 percent of samples)

- Strontium-90 (minimum 25 percent of samples)

Add sentences to end of paragraph 4: "Isotopic americium will be measured using analytical methods equivalent or superior to SOP 780/714 (Paragon, 1997). Minimum reporting limits for gamma-emitting radionuclides are 0.2 picocuries per gram $(\mathrm{pCi} / \mathrm{g})$ for soil and 20 picocuries per liter $(\mathrm{pCi} / \mathrm{L})$ for water $(\mathrm{DOE} / \mathrm{NV}, 1996)$. Minimum reporting limits for isotopic americium are $0.05 \mathrm{pCi} / \mathrm{g}$ for soil and $0.10 \mathrm{pCi} / \mathrm{L}$ for water (Paragon, 1997). The relative percent differences and percent recoveries for isotopic americium are the same as those listed for isotopic plutonium in Table 3-1 of the Leachfield Work Plan."

\section{Section 4.1}

Replace bullet eight with the following two bullets:

- "Analyze soil samples for total VOCs, total SVOCs, total RCRA metals, TPH (oil/diesel-range organics), PCBs, and gamma-emitting radionuclides.

- Analyze soil samples for isotopic uranium, isotopic plutonium, isotopic americium, and strontium-90 if radiological field screening levels are exceeded. If this percentage of samples does not meet the 25 percent minimum, then additional samples will be selected for these analyses at Site Supervisor's discretion."

\section{Section 4.2.3.4}

Change sentence to "Soil adjacent to obvious breaches located during the collection system video survey will be sampled using direct push methods."

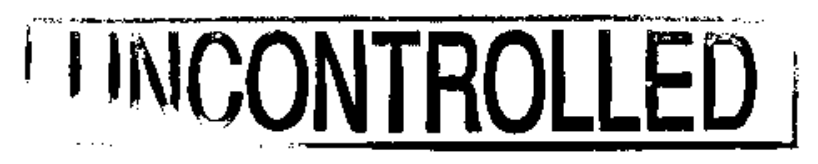




\section{RECORD OF TECHNICAL CHANGE}

Technical Change No.

Page 3 of 3

Section 7,0

Add references:

"U.S. Department of Energy, Nevada Operations Office. 1999. Corrective Action Investigation Plan for Corrective Action Unit 266: Area 25 Building 3124 Leachfield, Nevada Test Site, Nevada, Rev. 1, DOE/NV--529. Las Vegas, NV."

"Paragon Analytics, Inc. 1997. Laboratory Quality Assurance Plan, Revision 3. Fort Collins, Colorado."

The project time will be (Increased)(Decreased)(Unchanged) by approximately _ _ 0 days

Applicable Project-Specific Document(s):

Corrective Action Investigation Plan for Corrective Action Unit 266: Area 25 Building 3124 Leachfield, Nevada Test Site, Nevada, Rev. 1, DOE/NV--529-REV 1. U.S. Department of Energy, Nevada Operations Office, January, 1999.

$\mathrm{CC}$ :

Approved By:
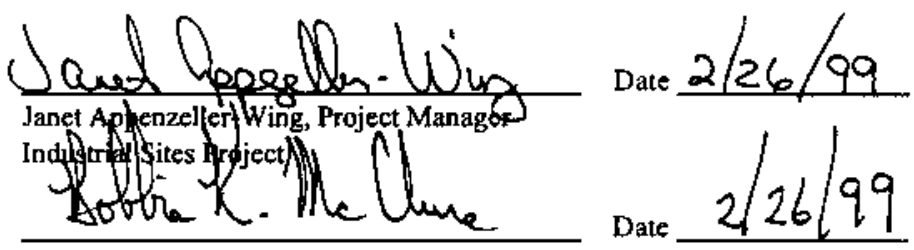

Runore C. Wycoff, Division Director

Environmental Restoration Division

Client Notified

Yes

$\mathrm{No}$

Date

Contract Change Order Required Yes _ No

Contract Change Order No 


\section{Table of Contents}

List of Figures . . . . . . . . . . . . . . .

List of Acronyms and Abbreviations $\ldots \ldots \ldots \ldots \ldots \ldots \ldots \ldots \ldots \ldots \ldots \ldots \ldots \ldots \ldots \ldots$

Executive Summary $\ldots \ldots \ldots \ldots \ldots \ldots \ldots \ldots \ldots \ldots \ldots \ldots \ldots \ldots \ldots \ldots \ldots \ldots \ldots \ldots \ldots$

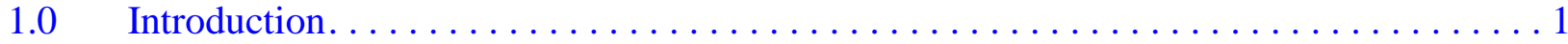

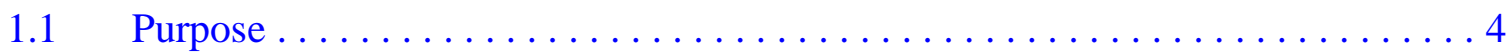

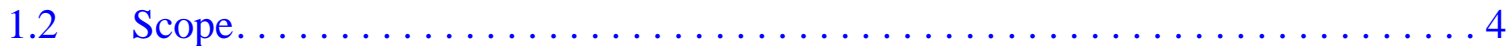

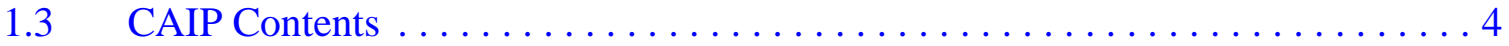

$2.0 \quad$ Facility Description. . . . . . . . . . . . . . . . . 6

$2.1 \quad$ Physical Setting. . . . . . . . . . . . . . . . . . 6

2.2 Operational History. . . . . . . . . . . . . . . . . . . 6

2.2.1 Acid Waste Leaching Pit (CAS No. 25-05-07) . . . . . . . . . . . 7

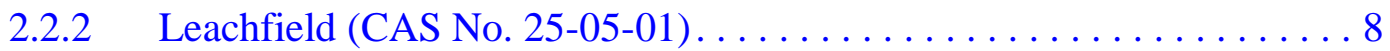

2.2.3 Collection System Description . . . . . . . . . . . . . . . . 9

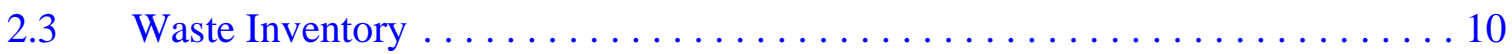

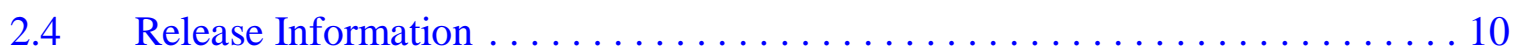

2.5 Investigative Background . . . . . . . . . . . . . . . . . . 11

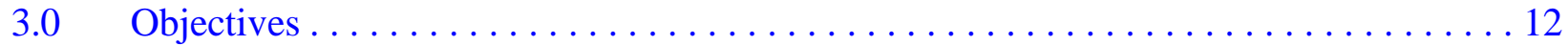

$3.1 \quad$ Conceptual Site Model . . . . . . . . . . . . . . . . . . . . . . . . . . 12

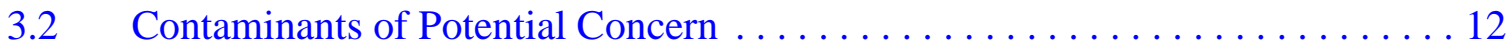

3.3 Preliminary Action Levels . . . . . . . . . . . . . . . . . 13

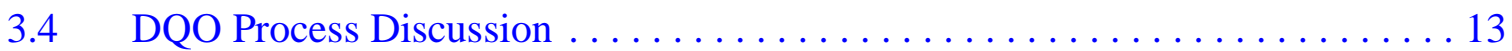

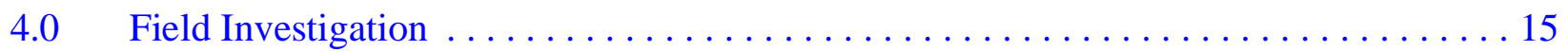

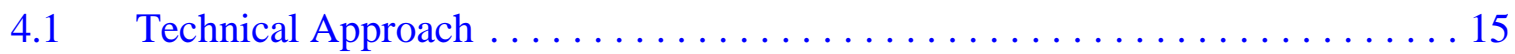

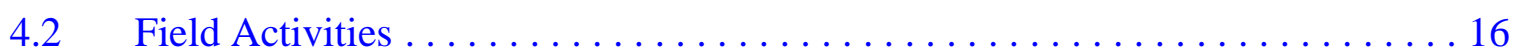

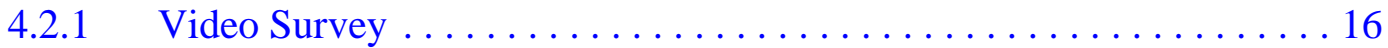

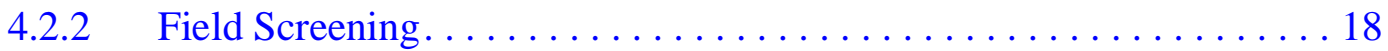

4.2.3 Collection System Sampling Activities . . . . . . . . . . . . . . . 18

4.2.3.1 Acid Waste Leaching Pit Samples ... . . . . . . . . . . . 20

4.2.3.2 Initial Outfall Samples . . . . . . . . . . . . . . . 20 


\section{Table of Contents (Continued)}

4.2.3.3 Second Outfall Samples ................. 20

4.2.3.4 Other Samples ...................... 21

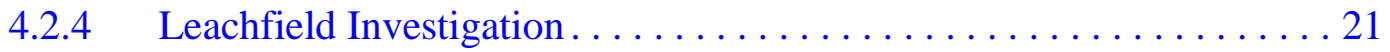

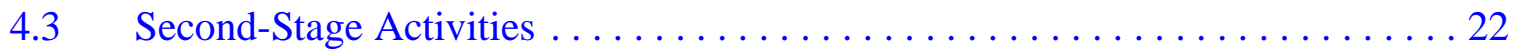

$5.0 \quad$ Waste Management. . . . . . . . . . . . . . . . . . . . . 23

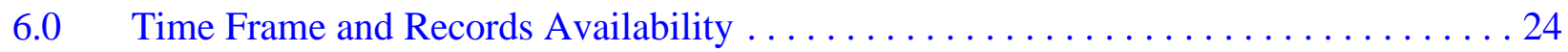

6.1 Time Frame. . . . . . . . . . . . . . . . . . . . . . 24

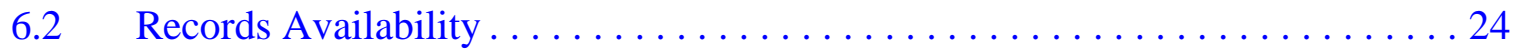

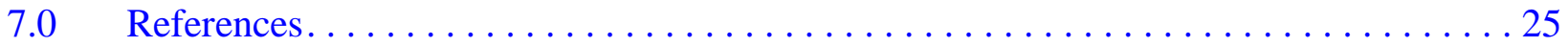

\section{Appendix A - Data Quality Objectives Worksheets}

A.1.0 Data Quality Objectives Worksheets for the Area 25 Test Cell A

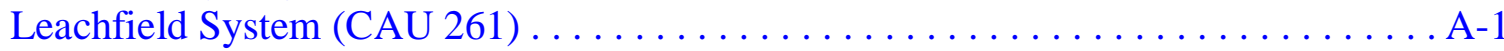

A.1.1 Members of the Scoping Team. . . . . . . . . . . . . . . . . . A-1

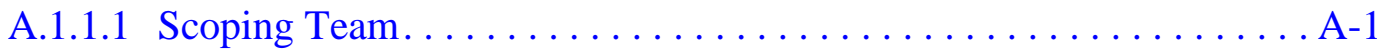

A.1.1.2 Core Decision Team. . . . . . . . . . . . . . . . . . A-1

A.1.1.3 Primary Decision Makers. . . . . . . . . . . . . . . . . A-1

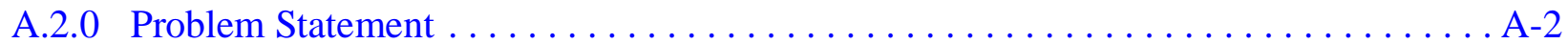

A.2.1 State the Problem . . . . . . . . . . . . . . . . . . .

A.2.2 Describe the Site History and List Known or Suspected Sources of Contamination . . . . . . . . . . . . . . A-2

A.2.2.1 Descriptions of Processes in Building 3124 That Served as Potential Waste Sources. . . . . . . . . . . . . . . A-2

A.2.2.2 Analytical Results from Sampling Efforts . . . . . . . . . . . . A-2

A.2.3 List Uncertainties and Develop a Preliminary Estimate of Variability . . . . . A-3

A.3.0 Develop/Refine the Conceptual Model. . . . . . . . . . . . . . . . . . . . A-4

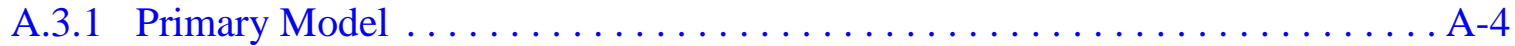

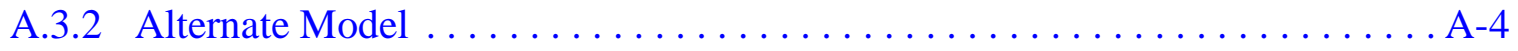




\section{Table of Contents (Continued)}

A.4.0 Identify the Decision. . . . . . . . . . . . . . . .

A.4.1 Select the Appropriate Decision for the Current Phase

of the Site Assessment Process . . . . . . . . . . . . . . . . . . A-5

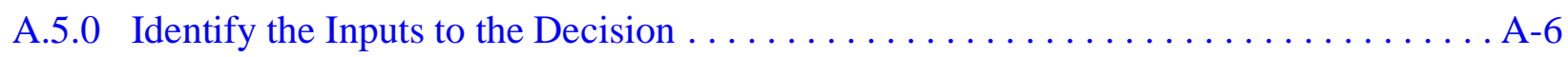

A.5.1 Identify the Information Inputs Needed to Resolve the Decision and

Prepare a List of All of the Data Needed to Resolve the Decision. . . . . . . . . A-6

A.5.1.1 Contaminant Identification . . . . . . . . . . . . . . . . . . A-6

A.5.1.2 Action Level Exceedence . . . . . . . . . . . . . . . . . . . . . . . A-6

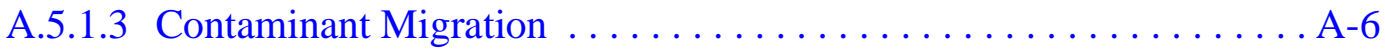

A.5.1.4 Risk Evaluation . . . . . . . . . . . . . . . . . . . A -6

A.5.1.5 Waste Management ... . . . . . . . . . . . . . . . . A-7

A.5.2 List Types of Contaminants and Affected Media . . . . . . . . . . . . A-7

A.5.3 Identify Potential Sampling Approaches and

Appropriate Analytical Methods . . . . . . . . . . . . . . . A-7

A.5.3.1 Appropriate Analytical Methods . . . . . . . . . . . . . . A-7

A.6.0 Define the Boundaries of the Study $\ldots \ldots \ldots \ldots \ldots \ldots \ldots \ldots \ldots \ldots \ldots \ldots$

A.6.1 Define the Geographic Areas of the Field Investigation . . . . . . . . . . A-8

A.6.2 Define the Temporal Boundaries of the Decision $\ldots \ldots \ldots \ldots \ldots \ldots \ldots$ A .8

A.6.2.1 The Time Frame to Which the Study Data Apply

Depends on the Following ................

A.6.2.2 Determine When to Collect Data . . . . . . . . . . . . . . . . . A-8

A.6.2.3 Define Relevant Time Constraints . . . . . . . . . . . . . . . . . . A-8

A.6.3 Identify Any Practical Constraints on Data Collection . . . . . . . . . . A-8

A.7.0 Develop a Decision Rule - Define a Logical Basis for

Choosing Among Alternative Actions . . . . . . . . . . . . . . . . . A-10

A.7.1 Specify the Action Level or Preliminary Action Level

for the Decision. . . . . . . . . . . . . . . . . . . . A-10

A.7.2 Specify the Variables Acting on the Corrective Action Decisions. . . . . . . . A-10

A.8.0 Specify Acceptable Limits on Decision Errors. . . . . . . . . . . . . . . A-11

A.8.1 Specify a Range of Possible Parameter Values Where the

Consequences of Decision Errors are Relatively Minor. 


\section{Table of Contents (Continued)}

A.8.2 Assign Probability Values to Points Above and Below the Action Level that Reflect the Acceptable Probability for the Occurrences of Decision Errors

A.8.3 Check for Consistency - Check the Limits on Decision Errors to Ensure that They Accurately Reflect the Decision Maker's Concerns About the Relative Consequences for Each Type of Decision Error

A.9.0 Optimize the Design - Outline a Sampling Design, Specifying the Operational Details of the Sampling Plan Which Falls Within the Project's Constraints . . . . . . . . . . . . . . . . . . . . . A-12

A.9.1 Develop General Sampling and Analysis Design Alternatives . . . . . . . . . A-12

A.9.1.1 Develop a Preliminary Estimate of Variability . . . . . . . . . . . A A-12

A.9.1.2 Develop a Sampling Strategy for the Site that Specifies All of the Previously Defined Data Quality Objectives . . . . . . . . A-12

A.9.2 Select the Most Resource-Effective Design that Satisfies All of the DQOs .. A-12

Appendix B - Existing Water \& Sewer Layout, Test Cell "A" Plan

Appendix C - Document Review Sheet 


\section{List of Figures}

Number

1-1 Nevada Test Site ............................ 2

1-2 CAU 261, Area 25, Test Cell A Leachfield .................... 3

4-1 Area 25 Test Cell A Sewer Drains and Outfalls . . . . . . . . . . . . . . . . . 17

4-2 CAU 261, Area 25, Test Cell A Leachfield Proposed Sampling Locations. . . . . . 19

B.1-1 Existing Water \& Sewer Layout Test Cell "A" Plan . . . . . . . . . . . . . . B-1 


\section{List of Acronyms and Abbreviations}

ASTM American Society for Testing and Materials

AWLP Acid Waste Leaching Pit

bgs Below ground surface

BN Bechtel Nevada Corporation

CADD Corrective Action Decision Document

CAIP Corrective Action Investigation Plan

CAS Corrective Action Site(s)

CAU Corrective Action Unit(s)

CFR Code of Federal Regulations

COPC Contaminant(s) of potential concern

$\mathrm{cm} \quad$ Centimeter(s)

DOE U.S. Department of Energy

DOE/NV U.S. Department of Energy, Nevada Operations Office

DOT U.S. Department of Transportation

DQO Data Quality Objective(s)

EPA U.S. Environmental Protection Agency

ETL Equipment Testing Laboratory

FFACO Federal Facility Agreement and Consent Order

ft $\quad$ Foot (feet)

gal Gallon(s)

G-M Geiger-Muller

HASP Health and safety plan

IDW Investigation-derived waste

in. $\operatorname{Inch}(\mathrm{es})$

km Kilometer(s)

L $\quad$ Liter(s) 


\section{List of Acronyms and Abbreviations (Continued)}

$\begin{array}{ll}\text { m } & \text { Meter(s) } \\ \text { mi } & \text { Mile(s) } \\ \text { NAC } & \text { Nevada Administrative Code } \\ \text { NDEP } & \text { Nevada Division of Environmental Protection } \\ \text { NRDS } & \text { Nuclear Rocket Development Station } \\ \text { NTS } & \text { Nevada Test Site } \\ \text { PAL } & \text { Preliminary action level } \\ \text { PRG } & \text { Preliminary Remediation Goal(s) } \\ \text { QAPP } & \text { Quality Assurance Project Plan } \\ \text { QA/QC } & \text { Quality assurance/quality control } \\ \text { RCRA } & \text { Resource Conservation and Recovery Act } \\ \text { REECo } & \text { Reynolds Electrical \& Engineering Company, Inc. } \\ \text { SSHASP } & \text { Site-specific health and safety plan } \\ \text { SVOC } & \text { Semivolatile organic compound(s) } \\ \text { TCLP } & \text { Toxicity characteristic leaching procedure } \\ \text { TPH } & \text { Total petroleum hydrocarbons } \\ \text { TTF } & \text { Treatability Test Facility } \\ \text { VOC } & \text { Volatile organic compound(s) }\end{array}$




\section{Executive Summary}

The Corrective Action Investigation Plan for Corrective Action Unit 261, the Area 25 Test Cell A Leachfield System, has been developed in accordance with the Federal Facility Agreement and Consent Order that was agreed to by the U.S. Department of Energy, Nevada Operations Office; the State of Nevada Division of Environmental Protection; and the U.S. Department of Defense. Corrective Action Unit 261 consists of Corrective Action Sites 25-05-01 and 25-05-07, respectively known as the Leachfield and the Acid Waste Leach Pit.

This Corrective Action Investigation Plan is used in combination with the Work Plan for Leachfield Corrective Action Units: Nevada Test Site and Tonopah Test Range, Nevada (DOE/NV 1998b). The Leachfield Work Plan was developed to streamline investigations at leachfield Corrective Action Units by incorporating management, technical, quality assurance, health and safety, public involvement, field sampling, and waste management information common to a set of Corrective Action Units with similar site histories and characteristics into a single document that can be referenced. This Corrective Action Investigation Plan provides investigative details specific to Corrective Action Unit 261.

Corrective Action Unit 261 is located south of Building 3124 which is southwest and adjacent to Test Cell A (see Figure 1-2 in the Corrective Action Investigation Plan). Test Cell A was operational during the 1960s to test nuclear rocket reactors in support of the Nuclear Rocket Development Station (SNPO, 1970). Operations within Building 3124 from 1962 through 1972 have resulted in liquid waste releases to the Leachfield and the Acid Waste Leach Pit (DOE, 1988a). The surface and subsurface soils in the vicinity of the collection system and leachfield have potentially been impacted by radioactive and other contaminants of potential concern associated with decontamination activities of equipment from Test Cell A.

Based on site history collected to support the Data Quality Objectives process, contaminants of potential concern for the site include radionuclides and Resource Conservation and Recovery Act characteristic volatile organic compounds, semivolatile compounds and metals. A conceptual site model for the leachfield Corrective Action Units was developed in the Leachfield Work Plan. No Corrective Action Unit-specific deviations from the model were identified during the Data Quality Objectives process for Corrective Action Unit 261. 
The technical approach for investigating this Corrective Action Unit consists of the following activities:

- Preparing an evaluation of components of the leachfield collection system

- Conducting a radiological survey

- Conducting a video survey of subsurface piping

- Conducting discrete field and radiological screening

- Conducting near-surface sampling within the drainage channel

- Conducting subsurface sampling at the Acid Waste Leach Pit

- Sampling the contents of the septic tank

- Collecting environmental samples for laboratory and geotechnical/hydrological analyses, and waste management purposes

- Conducting subsurface sampling from soil borings capable of reaching the expected vertical extent of contaminants of potential concern

- Logging core recovered from boreholes to assess soil characteristics

Additional sampling and analytical details are presented in Section 4.0 of the Corrective Action Investigation Plan and in the Leachfield Work Plan. Details of the waste management strategy for the Corrective Action Unit are included in the Leachfield Work Plan.

Under the Federal Facility Agreement and Consent Order, the Corrective Action Investigation Plan will be submitted to the Nevada Division of Environmental Protection for approval. Field work will be conducted following approval of the plan. The results of the field investigation will support a defensible evaluation of corrective action alternatives in the Corrective Action Decision Document. 


\subsection{Introduction}

This Corrective Action Investigation Plan (CAIP) has been developed in accordance with the Federal Facility Agreement and Consent Order (FFACO) that was agreed to by the U.S. Department of Energy, Nevada Operations Office (DOE/NV); the State of Nevada Division of Environmental Protection (NDEP); and the U.S. Department of Defense (FFACO, 1996). The CAIP is a document that provides or references all of the specific information for investigation activities associated with Corrective Action Units (CAUs) or Corrective Action Sites (CASs). According to the FFACO (FFACO, 1996), CASs are sites potentially requiring corrective action(s) and may include solid waste management units or individual disposal or release sites. Corrective Action Units consist of one or more CASs grouped together based on geography, technical similarity, or agency responsibility for the purpose of determining corrective actions.

This CAIP contains the environmental sample collection objectives and the criteria for conducting site investigation activities at CAU 261, the Area 25 Test Cell A Leachfield System, which is located in Area 25 at the Nevada Test Site (NTS). The NTS is approximately 88 kilometers $(\mathrm{km})$ (55 miles [mi]) northwest of Las Vegas, Nevada (Figure 1-1). As presented in Figure 1-2, CAU 261 is comprised of CASs 25-05-01 and 25-05-07, respectively known as the Leachfield and the Acid Waste Leach Pit (AWLP) (FFACO, 1996).

The leachfield is an area with dimensions of approximately 23 by 17 meters (m) ( 75 by 55 feet [ft]) and is located south of Building 3124, which is southwest and adjacent to Test Cell A. Test Cell A was operational during the 1960s to test nuclear rocket reactors in support of the Nuclear Rocket Development Station (NRDS) (SNPO, 1970). Various operations within Building 3124, from 1962 through 1972, have resulted in liquid waste releases to the leachfield and the AWLP (DOE, 1988a). The surface and subsurface soils in the vicinity of the collection system and leachfield have potentially been impacted by radioactive and other contaminants of potential concern (COPCs) associated with decontamination activities of equipment from Test Cell A. 


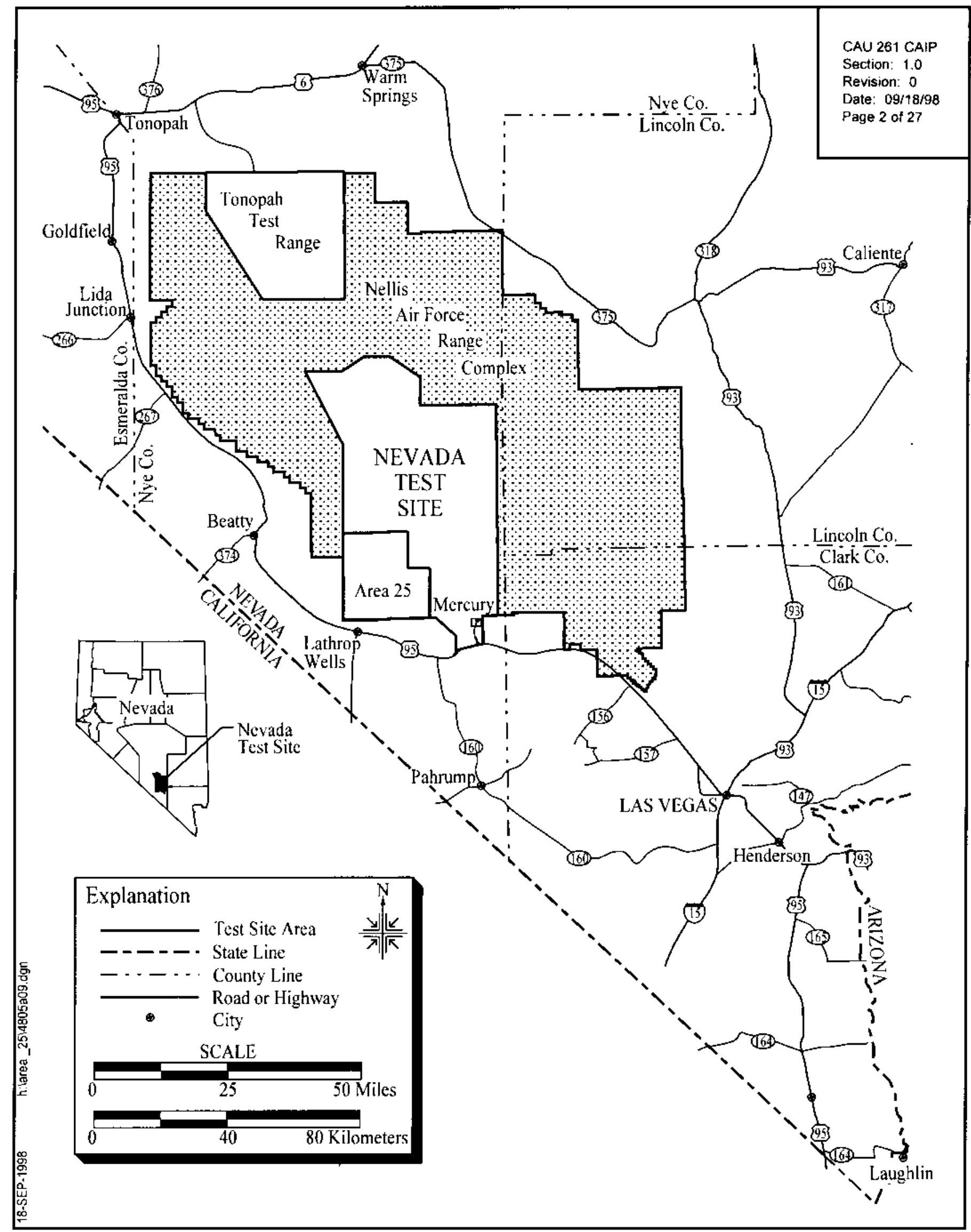

Figure 1-1

Nevada Test Site 


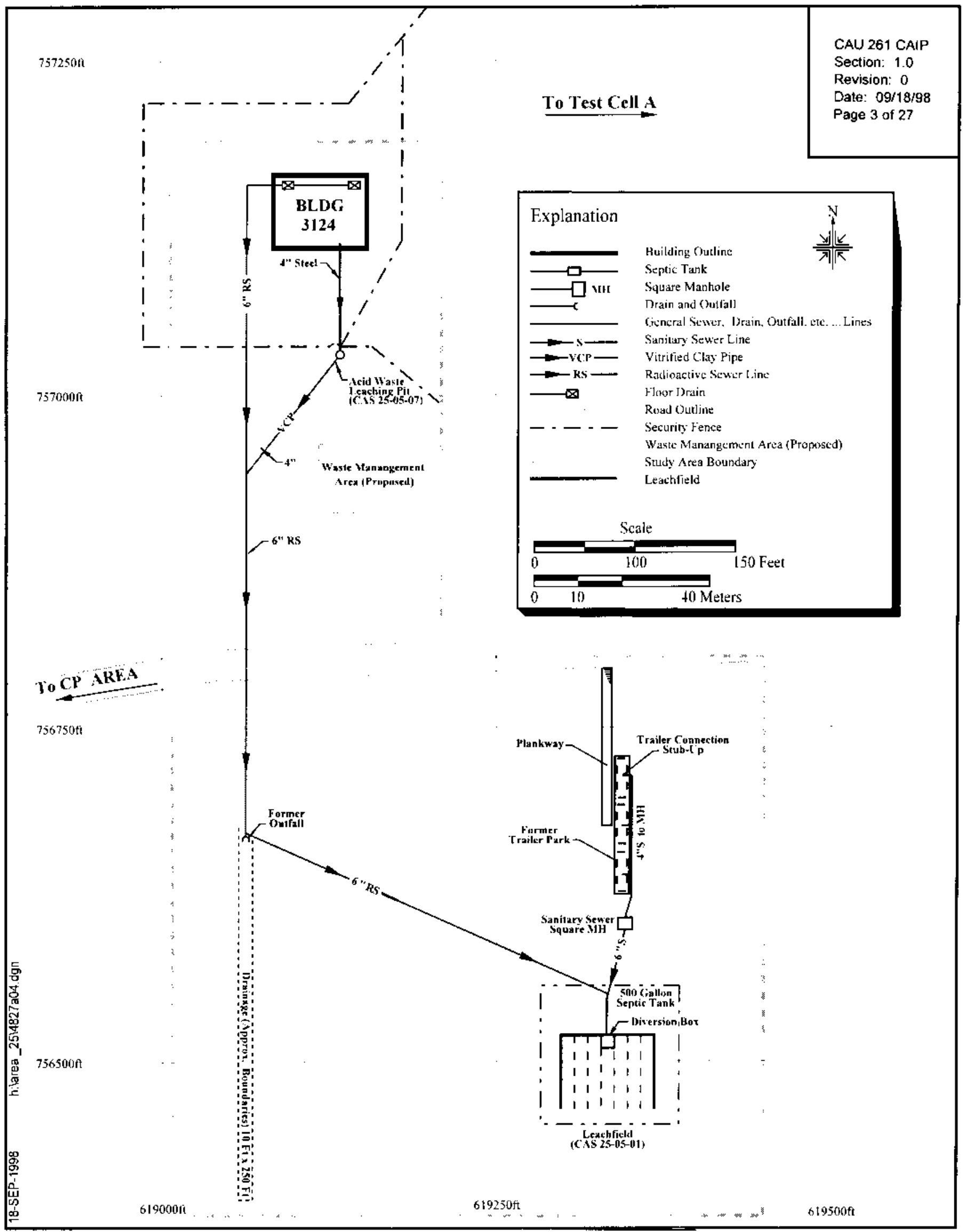

Figure 1-2

CAU 261, Area 25, Test Cell A Leachfield 


\subsection{Purpose}

This CAIP supports the investigation of the nature and extent of COPCs at CAU 261. The general purpose of corrective action investigations is described in the Work Plan for Leachfield Corrective Action Units: Nevada Test Site and Tonopah Test Range, Nevada (DOE/NV, 1998b), hereafter referred to as the Leachfield Work Plan.

\subsection{Scope}

The scope of this CAIP is to resolve the problem statement identified in the Data Quality Objective (DQO) process (see Appendix A), which is that acidic and alkaline rinses, degreasers, solvents, and radioactive effluents may have been released at the CAU and that existing data are insufficient to support the development and evaluation of potential corrective actions and selection of a preferred corrective action for the CAU. Therefore, the scope of the corrective action investigation at the CAU includes the following activities to answer the problem statement:

- Preparing an evaluation of components of the leachfield collection system

- Conducting a radiological survey

- Conducting a video survey of subsurface piping

- Conducting discrete field and radiological screening

- Conducting near-surface sampling within the drainage channel

- Conducting subsurface sampling at the AWLP

- Sampling the contents of the septic tank

- Collecting environmental samples for laboratory and geotechnical analyses, and waste management purposes

- Conducting subsurface sampling from soil borings capable of reaching the expected vertical extent of COPCs

- Logging core recovered from boreholes to assess soil characteristics

\subsection{CAIP Contents}

Section 1.0 of this CAIP provides an introduction to this project, including the purpose and scope for this corrective action investigation. The remainder of the document details the investigation strategy. The FFACO (1996) requires that CAIPs address the following elements:

- Management

- Technical aspects

- Quality assurance

- Health and safety 
- Public involvement

- Field sampling

- Waste management

The managerial aspects of this project are discussed in the DOE/NV Project Management Plan (DOE/NV, 1994) and the site-specific Field Management Plan that will be developed prior to field activities. The technical aspects of this CAIP are referenced from the Leachfield Work Plan, and contained in Section 3.0 and Section 4.0 of this document and in the DQO summary presented in Appendix A. General field and laboratory quality assurance and quality control (QA/QC) issues, including collection of QC samples, are presented in the Industrial Sites Quality Assurance Project Plan (QAPP) (DOE/NV, 1996). The health and safety aspects of this project are documented in the Environmental Restoration Project Health and Safety Plan (HASP) (DOE/NV, 1998a) and will also be supplemented with a site-specific HASP (SSHASP) written prior to the start of field work. No CAU-specific public involvement activities are planned at this time; however, an overview of public involvement is documented in the "Public Involvement Plan" in Appendix V of the FFACO (1996). Field sampling activities are discussed in the Leachfield Work Plan and in Section 4.0 of this CAIP; waste management issues are discussed in the Leachfield Work Plan and in Section 5.0 of this CAIP. The project schedule and records availability information for this CAIP are discussed in the Leachfield Work Plan and in Section 6.0 of this CAIP. Section 7.0 provides a list of project references. 


\subsection{Facility Description}

\subsection{Physical Setting}

The CAU is located at the Test Cell A Facility in Area 25 of the NTS, 46 to $52 \mathrm{~m}$ (150 to $200 \mathrm{ft}$ ) south of Road F (south-southeast of Building 3124).

General background information pertaining to the history of NTS and Area 25, a geologic assessment, and an overview of the area hydrogeology including depths to groundwater are provided in the Yucca Mountain Site Characterization Plan (DOE, 1988b) and in Appendix A of the Leachfield Work Plan.

\subsection{Operational History}

The original purpose of Building 3124, also referred to as the Equipment Testing Laboratory (ETL), was to support reactor test facilities at the NRDS (SNPO, 1970). Building 3124 was constructed in 1962 (SNPO, 1970). The building was largely unoccupied between 1972 and 1991 (Finney, 1998). During NRDS operations, the ETL contained equipment for water flow testing, gas flow testing, static pressure testing, equipment maintenance and cleaning, and limited analytical work (Harris, undated). The CAU 261 leachfield received effluent from the Flow Bay and the Cleaning Room in Building 3124. Other rooms in this building were served by a sanitary leachfield, which is addressed separately as CAU 266. Operations in the Flow Bay which generated radioactive effluent are not known; however, it is believed that the drains were used for the disposal of liquid wastes generated primarily by decontamination operations (DOE, 1988a). The Cleaning Room included an ultrasonic cleaning unit, two acid tanks, two alkaline tanks, a vapor degreaser, and a rinsate tank (Harris, undated).

Building 3124 drains that received inputs from past operations were not used after the cessation of Test Cell operations in 1972 (Shotten, 1998). Building 3124 was refurbished for use as the Treatability Test Facility (TTF) Building and was in operation from 1993 through 1994. The TTF was part of a DOE experiment conducted by a DOE contractor to study radioactively contaminated soil remediation techniques. Clean-up for the project started in 1991 and operations started in 1993. The floor drains which previously fed the leachfield were grouted shut prior to commencement of 
TTF operations (Finney, 1998) and did not contribute effluent to the CAU 261 leachfield system. The building is presently unoccupied. Brief descriptions of the two CASs are provided in Section 2.2.1 and Section 2.2.2, and the entire site is discussed in Section 2.2.3.

The U.S. Department of Energy (DOE) Environment, Safety and Health, Office of Environmental Audit reviewed available historical information, collected soil samples, and prepared an environmental survey as a preliminary report in April 1988 (DOE, 1988a). The survey team discovered that there is very little documentation regarding the past activities at the NRDS facilities. On-site personnel know very little about the operations that took place when the site was active (DOE, 1988a).

\subsubsection{Acid Waste Leaching Pit (CAS No. 25-05-07)}

The AWLP is located approximately $23 \mathrm{~m}$ (75 ft) south of Building 3124, outside the security fence. Locations and layout of subsurface features are based on inspections and interpretations derived from the Bechtel Nevada Corporation (BN) archived engineering drawings, 25-TC-A-C1, J6-SK: JA-381 and TCA-PAA-0003 (BN, 1997). The AWLP consists of a 10-centimeter (cm) (4-inch [in.]) inlet from Building 3124, a gravel-filled pit, and a 10-cm (4-in.) pipe exiting the AWLP which now connects with the radioactive sewer line. The pit appears to have been constructed from a subgrade, 210 liter (L) (55 gallon [gal]) drum with a heavy steel lid. The AWLP has been partially filled with limestone gravel designed to neutralize acidic wastewater introduced to the pit from the ETL (Miller, 1984).

The 25-TC-A-C1 engineering drawing presents a composite of CAS 25-05-07 and CAS 25-05-01 components, except the 10-cm (4-in.) pipe/AWLP connection, and is presented as Appendix B (BN, 1997). The connection to the radioactive sewer discharge line is further discussed in Section 2.2.3. The AWLP was fed by a 10-cm (4-in.) line exiting an "open drain" or grated trench within the Cleaning Room in Building 3124. During NRDS facility operations the room was used for cleaning and degreasing various parts and components (SNPO, 1970). Equipment used included an ultrasonic cleaning unit, two acid tanks, two alkaline tanks, a vapor degreaser, and a rinse tank. All equipment except for the ultrasonic cleaning unit was positioned over the "open drain" (Harris, undated). 
Inside the AWLP, a physical gap exists between the sections of pipe. It is not known how, or if, the section of pipe exiting the AWLP received effluent. The pipe may have operated as an overflow for effluent percolating downward through the gravel in the AWLP, or a section of pipe that allowed direct flow through the AWLP to the radioactive sewer line may have been subsequently removed.

\subsubsection{Leachfield (CAS No. 25-05-01)}

Corrective Action Site 25-05-01 includes a 1900 L (500 gal) septic tank, associated collection system piping, an inflow (upstream) manway, and an associated leachfield (Appendix B). The dimensions of the leachfield as specified at installation were approximately 23 by $17 \mathrm{~m}$ (75 by $55 \mathrm{ft}$ ). The leachfield is believed to be constructed of eight parallel pipes that drain to the south. A drawing showing a cross-section with depths and details of installation(s) is not available.

The first effluent received by the leachfield was from the trailer park. Documentation reviewed indicates that the leachfield was constructed for sanitary effluent disposal and intended for use solely as a sanitary system by the former trailer park (BN, 1997).

Process wastewater discharge lines from Building 3124 did not originally terminate into the leachfield. The 15-cm (6-in.) discharge line was eventually routed and connected into the leachfield after a series of discharge line extensions were completed (BN, 1997). The extensions were apparently conducted in two stages and are addressed in Section 2.2.3. A field visit confirmed that the last segment completing the connection to the leachfield has been installed (Evenson, 1998). Evidence for this completed connection is an exposed section of pipe including the junction, but the date this connection was completed into the leachfield is unknown. The completed connection is shown only in the Reynolds Electrical \& Engineering Company, Inc. (REECo) drawing (25-TC-A-C1), Existing Water \& Sewer Layout Plan, Test Cell “A,” dated 1984 (BN, 1997). This drawing is provided as Appendix B (BN, 1997). This drawing post-dates the closure of ETL operations, but it is the only available drawing that shows the interconnection of these features.

This interpretive chronology of the installations and modifications is based on the available engineering drawings that have been compiled and listed in Section 2.2.1. 


\subsubsection{Collection System Description}

Further discussion of CAU physical components will refer collectively to all contributing underground components, exclusive of the leachfield and the AWLP, as the collection system. The collection system consists of a 15-cm (6-in.) radioactive sewer line exiting the Flow Bay in Building 3124, a segment of 10-cm (4-in.) pipe from the AWLP making the junction into the 15-cm (6-in.) line from the AWLP, a steel-pipe segment from Building 3124 to the AWLP, and a 10-cm (4-in.) sanitary sewer line originating at the former trailer park south of Road F (BN, 1997). Documentation reviewed labels the line as a radioactive line, and process knowledge indicates that this was a likely use (DOE, 1988a).

For convenience, the radioactive line will be referred to as "the 6-in. line" for the remainder of this CAIP. The 6-in. line from Building 3124 was apparently first extended, then connected to the leachfield via a second extension at a later date. Prior to extension of the 6-in. line to the leachfield, effluent was apparently released to the ground north of Road $\mathrm{F}$ (the initial outfall). The line was then extended south of Road F, to a subsequent outfall. Effluent from this outfall flowed into a drainage feature. The earliest available engineering drawing, (ETL Flow Bay Drain Extension - J6-SK: JA-381) is an "as-built" dated February 5, 1964 (BN, 1997). The period of time that the discharge line was open as an outfall and to the ditch is unknown. A Remote Sensing Laboratory aerial photograph, Number 652-2-21, shows evidence of an open sewer discharging to a drainage west of the leachfield (EG\&G, 1965).

The line was extended to connect the 6-in. line to the drainage, as indicated in a February 1964 as-built engineering drawing, J6-SK:JA-381, called the ETL Flow Bay Drain Extension (BN, 1997). This drawing shows the 6-in. line outfalling to the ground surface (post extension) at the northern end of the drainage feature (see Figure 1-2). Also performed during this operation was the connection of the 4-in. vitrified clay pipe segment from the AWLP into the 15-cm (6-in.) line north of Road F. The collection system routed effluent through a single point into the $1900 \mathrm{~L}$ (500 gal) septic tank inside the fenced area of the leachfield. Effluent left the septic tank, went to a diversion box, and then was discharged to the leachfield (BN, 1997).

As a result of the DQO scoping, the collection system has been added to the scope of this investigation (Appendix A). 


\subsection{Waste Inventory}

Information from interviews with former NTS workers (Finney, 1998 and Shotten, 1998), interpretations of engineering drawings (BN, 1997), descriptions of processes, and a brief list of chemical types used in potential source rooms (Harris, undated) indicate that industrial wastewaters were disposed in the collection systems. The DQO process evaluated available information, and a list of potential contaminants was developed (Appendix A).

Liquids typically associated with the ETL daily operations included acidic and alkaline bath waters, degreasers, cleaning agents, and decontamination solutions (DOE, 1988a). Records of liquid waste quantities discharged through the collection systems are not available.

Since the DQO scoping, documentation has been discovered stating that 9,000 L $(2,400$ gal $)$ of “contaminated water" was transferred in six 1500-L (400-gal) increments from Test Cell C (Nuclear Furnace) operations to the ETL during an 8 day period in January 1973 (IT, 1998). It is not known if this water was introduced into the CAU 261 leachfield system. No further evidence of routine transfer practices, history of liquid waste disposal, or documented events has been identified in the assessment phase of CAU 261.

\subsection{Release Information}

The source of potential contamination associated with the collection system is wastewater that was channeled from the building drains released to the ground surface via outfalls and through the base of the AWLP. Following the complete connection of the discharge lines to the leachfield, effluent was routed to the septic tank, and released into the leachfield. The leachfields were designed for liquid to be dispersed over an area just below the basement of installed leachfield materials, and to percolate down into the subsurface soil. The driving force for downward migration of the contamination was the discharge from the septic tank, which no longer exists. The possibility of leakage at points along the collection system exists, but there is no evidence of documented leaks or releases.

No details concerning the waste inventory within the source buildings during the various years of operation could be found. The quantities of wastewater generated or discharged during the operational periods is unknown (DOE, 1988a). 


\subsection{Investigative Background}

A soil sampling effort consisting of many NTS sites was performed by the DOE and the results presented in the Environmental Survey Preliminary Report, Nevada Test Site, Nevada (DOE, 1988a). Analytical results for "Test Cell A Leachfield" were presented and reviewed in the DQO scopings. Upon further review of the report, the analytical data may not be associated with CAU 261; therefore, the analytical results reported would be misleading if viewed as baseline data for this CAU. 


\subsection{Objectives}

A discussion of general objectives for leachfield CAUs is presented in Section 3.0 of the Leachfield Work Plan. Objectives addressed in this CAIP are based on the Leachfield Work Plan and CAU-specific DQOs. Unless otherwise noted, objectives for CAU 261 are identical to those developed in the Leachfield Work Plan.

\subsection{Conceptual Site Model}

The conceptual model for CAU 261 is analogous to the general leachfield conceptual model presented in Section 3.1 of the Leachfield Work Plan. The scope and strategy of this investigation may be revised if the conceptual model provided in this CAIP and applicable portions of the conceptual model provided in the Leachfield Work Plan fail. The CAU 261 conceptual model may fail if substantially different historical operational information is discovered or field observations demonstrate the nature or extent of contamination associated with the CAU is substantially different than anticipated. If necessary, a rescoping of the investigation will be conducted.

Atypical components included in CAU 261 are the AWLP and the drainage ditch outfalls. Investigation techniques outlined in the Leachfield Work Plan are suitable for investigating these unusual features. Contamination associated with the AWLP will be addressed as point-source subsurface contamination with a potential surface discharge component. Surface discharge may have resulted from the AWLP overflowing at some time during its operational history. No evidence suggests this actually occurred. Contamination associated with the outfalls will be addressed as surface and near-surface contamination. Soils beneath the outfall and along the drainage are potentially impacted.

\subsection{Contaminants of Potential Concern}

Potential types of contaminants that could be present were identified through a review of site history documentation, subjective process knowledge, and inferred activities associated with the CAU. Contaminants are expected to be similar to seepage from radioactive decontamination operations and light industrial sewage systems. 
The following list of COPCs for the site was developed during the DQO process:

- Volatile organic compounds (VOCs)

- Semivolatile organic compounds (SVOCs)

- Resource Conservation and Recovery Act (RCRA) metals

- Radionuclides

The following analytes will be measured:

- Total VOCs

- Total SVOCs

- Total RCRA Metals

- Gamma-Emitting Radionuclides

Laboratory analysis of the soil samples will provide the means for a quantitative measurement of the potential contaminants of concern. The analytical methods and minimum reporting limits for each analyte are provided in Table 3.1 of the Leachfield Work Plan.

Geotechnical and hydrological analysis will be performed according to the requirements of Section 3.2.1 of the Leachfield Work Plan.

\subsection{Preliminary Action Levels}

Screening levels for on-site field screening methods and preliminary action levels (PALs) for off-site analytical methods will be used to determine the presence of contamination. The screening levels and PALs appear in Section 3.3 of the Leachfield Work Plan and were agreed upon during the CAU-specific DQO process. For radiological constituents, PALs are the average concentrations found in an unimpacted area plus two standard deviations.

Total petroleum hydrocarbon (TPH) field screening and PALs are not applicable to this site as TPH is not a COPC.

\subsection{DQO Process Discussion}

Details of the DQO process are presented in Appendix A. The DQO results for CAU 261 indicated the need for a biased sampling approach. Due to potential subsurface migration of COPCs, an investigation consisting of subsurface sampling was identified. The COPCs agreed upon during the 
DQO process are provided in Section 3.2. Applicable analytical methods, reporting limits, and precision and accuracy requirements are provided in Table 3-1 of the Leachfield Work Plan. The precision and accuracy requirements provided in this table are those stated in the latest revision of the individual U.S. Environmental Protection Agency (EPA) Contract Laboratory Program Statements of Work. Data quality will be verified and evaluated as stated in the Leachfield Work Plan. 


\subsection{Field Investigation}

The following sections describe the investigation activities to be used at CAU 261. General field investigation activities are also discussed in Section 4.0 of the Leachfield Work Plan.

\subsection{Technical Approach}

Section 4.1 of the Leachfield Work Plan describes the general technical approach for investigating leachfield CAUs. Based on the general approach, the technical approach for CAU 261 consists of the following activities:

- Perform a radiological walkover survey

- Activity completed prior to CAU-specific DQO meeting

- Perform video and radiation surveys of discharge and outfall lines

- Mark approximate locations of leachfield distribution lines on the ground surface

- Collect surface soil samples from drainage ditch near former 6 in. line outfalls

- Collect subsurface soil samples in areas of the collection system

- Collect samples from soil underlying the leachfield distribution pipes

- Field screen subsurface soils

- Analyze soil samples for total VOCs, SVOCs, RCRA metals, and gamma spectroscopy

- Collect samples from native soils beneath the distribution system and analyze for geotechnical and hydrological parameters

This investigation strategy will allow the extent of contamination associated with the leachfield system to be established. In general, the intrusive investigation (drilling) will continue until the leachfield and the unsaturated interval are adequately investigated, as defined by identifying two consecutive intervals with contaminant concentrations below appropriate field screening levels and PALs as stated in Section 3.3. 


\subsection{Field Activities}

General field activities are discussed in the Leachfield Work Plan in Section 4.1. Those field activities specific to CAU 261 are described in the following sections. All sampling activities will be conducted in compliance with the Industrial Sites QAPP (DOE/NV, 1996). Requirements for field and laboratory environmental sampling are contained in the Industrial Sites QAPP (DOE/NV, 1996) and the Leachfield Work Plan.

Excavation associated with CAU 261 will be minimized due to the potential for radiological constituents in the soil. Some excavation may be required for video and radiological pipe surveys and to expose various collection system features for sampling. No excavation will be conducted within the posted radiological controlled area surrounding the radioactive leachfield. Excavated soil will be stored in a manner which will prevent run-on and run-off. Soil excavated during trenching operations will be returned to the excavation as close to its original location as possible upon completion of the excavation investigation activities.

\subsubsection{Video Survey}

A video and radiation survey will be conducted inside the discharge and outfall lines to map the piping associated with the collection system and lines leading to the leachfield if possible. This survey may not be possible for some lines because of small pipe diameters (i.e., less than $7.5 \mathrm{~cm}$ [3 in.] diameter), limited access, or pipe damage, blockage, or other factors. No attempt will be made to survey lines in the leachfield system beyond the septic tank within the radiological controlled area.

The camera and cable system with optional radiation detector (i.e., Geiger-Muller [G-M] tube) will be introduced through the $15-\mathrm{cm}(6-i n$.$) line from the junction at the former outfall. At least one$ additional entry point for the camera and cable system will be required. Other entry points may be accessed by excavating at the required locations. The joint between the $15-\mathrm{cm}$ (6-in.) line and the 10-cm (4-in.) AWLP line will be excavated to allow inspection of the joint, collection of a sample from soil underlying the joint if necessary, and introduction of the camera and cable system.

The video survey will evaluate the existence of unexpected contributing collection system lines from Test Cell A. Discharge lines originally terminating in outfalls may have been connected to the CAU 261 leachfield system. These outfalls are indicated with asterisks on Figure 4-1. If a tie-in is 


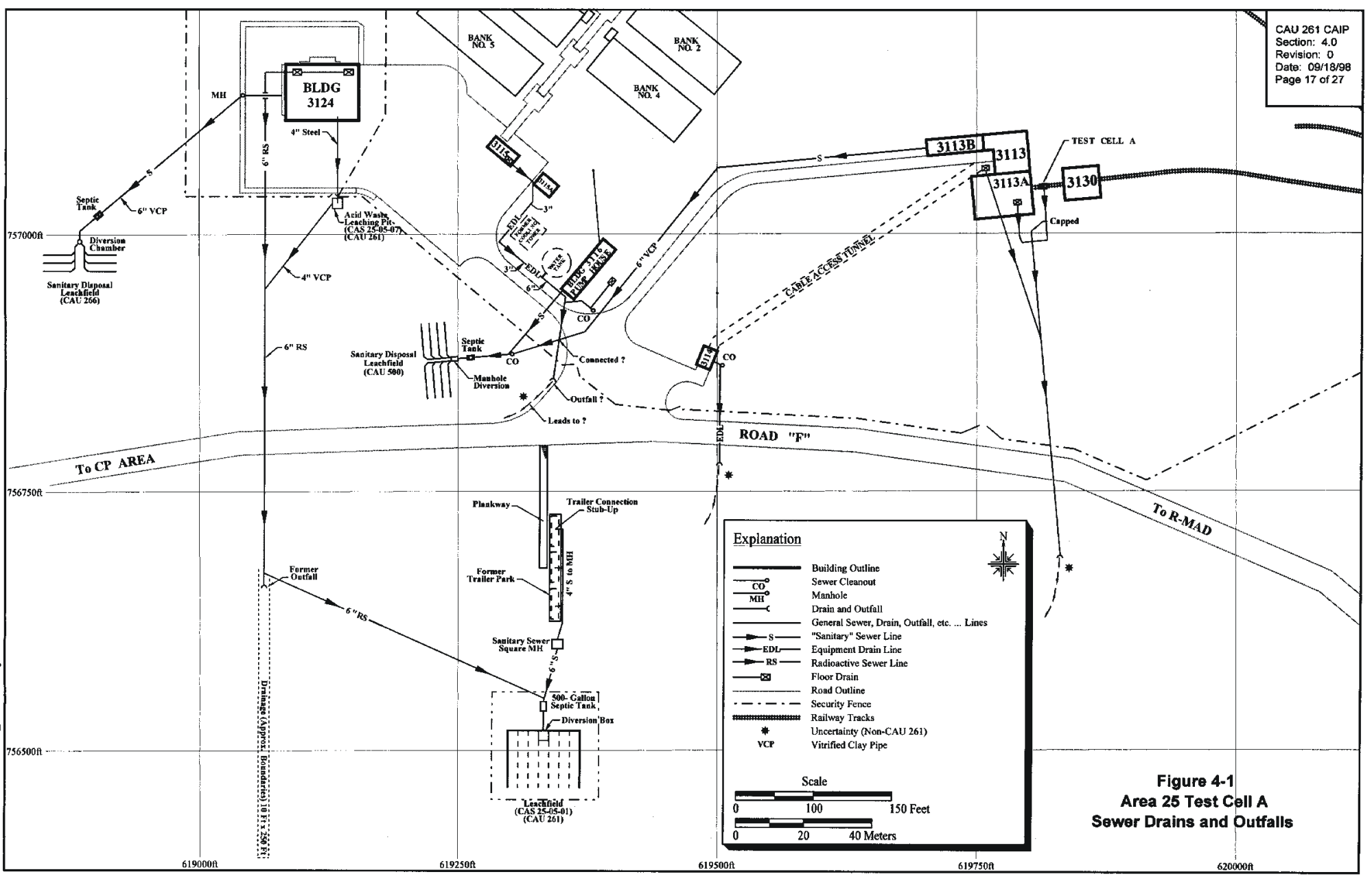


discovered the line will be investigated to the source (if possible) and sampling activities will be suspended until an action consensus is reached between members of the scoping team. The discovery of an unexpected contributing line may imply an additional source input and could increase the scope of the investigation.

\subsubsection{Field Screening}

Field screening for VOCs and radiological activity will be performed to guide the investigations and sample selection and assist with health and safety and waste management decisions. Field screening methodology is discussed in Section 4.1.3 of the Leachfield Work Plan. Field screening for TPH will not be conducted to prevent generation of mixed waste and because TPH is not a COPC at CAU 261.

\subsubsection{Collection System Sampling Activities}

A first stage of soil samples will be collected in four general areas to investigate possible release points along the collection system. The proposed sampling locations are shown in Figure 4-2. The four general areas are:

- The AWLP

- Two near-surface sample locations

- One subsurface sample location (directly below AWLP)

- The initial outfall

- Three near-surface sample locations

- The drainage feature below the second outfall

- Six near-surface sample locations

- Significant breaches along the collection system discovered during video survey

First-stage samples will also be collected from soil borings within the radiological controlled area surrounding the leachfield. These samples will include septic tank, diversion box, and distribution system samples as addressed in Section 4.2.4. 


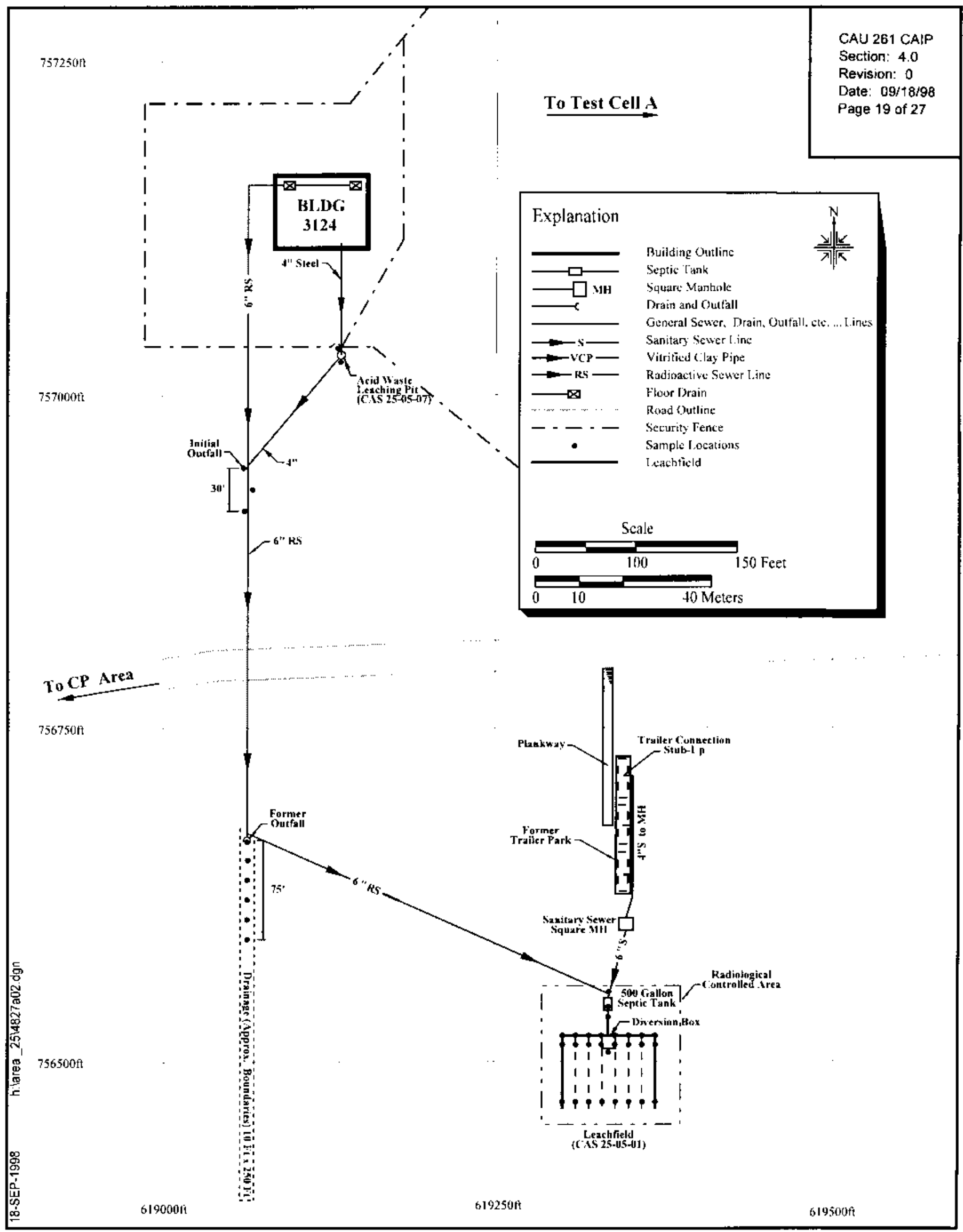

Figure 4-2

CAU 261, Area 25, Test Cell A Leachfield Proposed Sampling Locations 
Surface and near-surface samples will be collected using hand tools or direct push (i.e., Geoprobe ${ }^{\mathrm{TM}}$ ) methods. A second stage of samples described in Section 4.3 will be collected as step-outs or at greater depths below the first stage of samples if results show that concentrations are exceeding field screening levels and/or PALs.

\subsubsection{Acid Waste Leaching Pit Samples}

Near-surface samples will be collected at the AWLP at a depth of 0.1 to $0.4 \mathrm{~m}(0.25$ to $1.25 \mathrm{ft})$ below ground surface (bgs) to determine if soils have been impacted from possible overflow of the AWLP. Subsurface soil samples will be collected from a boring through the center of the AWLP. Samples will be collected at the interface between the gravel and the native soil. Additional samples will be collected from 1.5 to $1.8 \mathrm{~m}$ (5.0 to $6.0 \mathrm{ft}) \mathrm{bgs}$, from 3.0 to $3.4 \mathrm{~m}$ (10.0 to $11.0 \mathrm{ft}) \mathrm{bgs}$, or until two consecutive samples below field screening levels are recovered.

\subsubsection{Initial Outfall Samples}

As discussed in Section 2.3, surface soil north of Road F may have been contaminated by effluent from the ETL prior to extending the 15-cm (6-in.) line to the former outfall south of Road F. The area north of the road will be investigated by means of collecting three first-stage, near-surface soil samples from depth intervals of 0.1 to $0.4 \mathrm{~m}(0.25$ to $1.25 \mathrm{ft}) \mathrm{bgs}$. These locations are shown near the intersection of the 6 in. line and the AWLP discharge line in Figure 4-2.

\subsubsection{Second Outfall Samples}

The drainage feature presented in Figure 4-2 will be investigated by means of collecting a series of six first-stage, near-surface soil samples, from 0.1 to $0.4 \mathrm{~m}(0.25$ to $1.3 \mathrm{ft}) \mathrm{bgs}$. As discussed in the DQOs, the drainage banks physically define the east and west margins of the drainage area. The average width is estimated to be $3.0 \mathrm{~m}(10 \mathrm{ft})$. All six samples will be individually centered between the east and west margins and separated by $4.6 \mathrm{~m}(15 \mathrm{ft})$ in a direction down the drainage center, with the most northern sample at the former outfall. Step-out samples to define the lateral extent of contaminants will be collected approximately $1.5 \mathrm{~m}(5 \mathrm{ft})$ east and west from the drainage center, if necessary. Additionally, a decision was reached while developing the DQOs to define an end point of the drainage at $46 \mathrm{~m}(150 \mathrm{ft})$ from the mouth of the former outfall. The six first-stage sample locations are shown in Figure 4-2. 


\subsubsection{Other Samples}

Obvious breaches located during the collection system video survey will be exposed by excavating the pipe and collecting a sample from the soil underlying the disruption.

\subsubsection{Leachfield Investigation}

Because of the potential for radiological and hazardous contaminants, intrusive work within the radiological controlled area will be conducted using a direct push method (i.e., Geoprobe ${ }^{\mathrm{TM}}$ ) or soil borings. This will provide greater protection for workers and limit the amount of radioactive or mixed waste generated during the investigation. The benefits offered by excavation are limited because the location of the CAU 261 leachfield is well constrained within a posted radiological controlled area.

Portions of both the septic tank and distribution box for the CAU 261 leachfield are visible at the ground surface within the radiological controlled area. A total of four samples (including the contents of the septic tank, if possible) will be collected to investigate the septic tank and distribution box. The contents of the septic tank will be sampled through the accessible manway. Soil at both ends of the septic tank and the outflow end of the distribution box (see Figure 4-2) will be collected from depths of 1.5 to $1.8 \mathrm{~m}$ (5.0 to $6.0 \mathrm{ft}$ ) bgs using direct push methods (i.e., Geoprobe ${ }^{\mathrm{TM}}$ ) or soil borings. This is the estimated depth of connecting collection system piping and components at this portion of the leachfield, and samples recovered from this depth will be representative soil likely to have been impacted if breaches occurred.

The leachfield will be sampled along three parallel transects perpendicular to the distribution pipes. One transect will coincide with the distribution stems extending from the distribution box, another will be approximately $3.4 \mathrm{~m}$ (11 ft) from the distribution stems (the proximal end of the leachfield), and a third will be approximately $3 \mathrm{~m}(10 \mathrm{ft})$ from the distal end of the leachfield. The boreholes will be adjusted to coincide with locations near the distribution lines, resulting in sample locations with approximately 3.4-m (11-ft) horizontal separations. Sample locations are presented in Figure 4-2.

Soil samples will be collected from the sampling locations in native soil below distribution pipes and again $0.7 \mathrm{~m}(2.5 \mathrm{ft})$ below the base of the leachfield. The results of this first-stage sampling effort 
will be used to determine if deeper drilling (second stage) is needed to track the vertical extent of contamination and to help select the location(s) of any step-out soil borings.

Approximately 50 first-stage samples will be obtained within the area of the leachfield based on the conceptual model. Samples to be analyzed by the off-site laboratory will be selected based on the results of field screening and planned sampling intervals. The actual number of samples analyzed will depend on decisions made in the field. Additional (or fewer) characterization samples may be sent for off-site analysis based on field-screening results and the results of sample analyses when they become available.

A sample of the soil beneath the leachfield base/native soil interface will be collected to assess its geotechnical and hydrological characteristics. The sample will be collected within brass sleeves (or other, as appropriate) to preserve the natural physical characteristics of the soil. Additional geotechnical/hydrological samples may be collected based on the conditions encountered during the investigation. The geotechnical and hydrological analyses for these samples are presented in Table 3-2 of the Leachfield Work Plan.

\subsection{Second-Stage Activities}

Deeper or additional boreholes may be drilled as described in Section 4.1.2.1 of the Leachfield Work Plan if screening results indicate that contamination continues below or outside of the first-stage

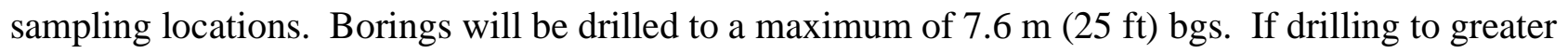
depths is necessary, boreholes will be advanced to a vertical depth of $15 \mathrm{~m}(50 \mathrm{ft}) \mathrm{bgs}$ or the limits of the rig. If drilling to depths past the limits of the rig is necessary, the project will be rescoped as appropriate.

Borehole samples may be required at greater depths or from new locations to adequately investigate the contamination extent. If necessary, initial step-out locations will be placed $4.6 \mathrm{~m}$ (15 ft) outside the margins of the leachfield. Boreholes will be advanced to appropriate depths to track the vertical extent of contamination and samples will be collected in 1.5-m (5-ft) intervals. 


\subsection{Waste Management}

Waste management activities to be performed for CAU 261 are addressed in Section 5.0 of the Leachfield Work Plan. All potential waste types/streams associated with the leachfield CAUs are covered in the Leachfield Work Plan. Based on process knowledge obtained for CAU 261, radioactive and possible hazardous and/or mixed wastes are anticipated at this site. There is no process knowledge that identifies a specific "listed" hazardous waste that was discharged to this leachfield. However, there is evidence that solvents used in the vapor degreasing unit may have been discharged to the leachfield. Consequently, if solvents are detected which are consistent with the vapor degreasing process, investigation-derived waste (IDW) may be characterized as "listed" hazardous waste per 40 CFR 261.31 (CFR, 1996). Action levels for IDW contaminants are as stated in Table 5.1 of the Leachfield Work Plan. Polychlorinated biphenyls and TPH are not anticipated COPCs at CAU 261.

Waste will be managed according to mixed waste requirements until laboratory analyses are received and a final waste determination is made. Radiological swipe samples may be conducted on reusable sampling equipment and the personal protective equipment and disposable sampling equipment waste streams exiting from within the controlled area at CAU 261 as stated in the Leachfield Work Plan.

Any IDW generated during this investigation will be segregated by waste stream and placed in U.S. Department of Transportation (DOT)-compliant containers appropriate for the type and amount of waste generated. The IDW generated at CAU 261 will be contained in DOT-compliant containers meeting the specifications outlined in the Leachfield Work Plan. 


\subsection{Time Frame and Records Availability}

\subsection{Time Frame}

After submittal of the Final CAIP to NDEP (FFACO milestone deadline of November 2, 1998), the following is a tentative schedule of activities (in calendar days):

- Day 0: Preparation for field work will begin.

- Day 60: The field work, including field screening and sampling, will begin. Samples will be shipped to meet lab holding times.

- Day 110: The field work will be completed.

- Day 185: The quality-assured laboratory analytical sample data will be available for review.

- The FFACO date for the Corrective Action Decision Document (CADD) is currently March 31, 1999, but an extension until September 1, 1999, has been requested.

\subsection{Records Availability}

Historic information and documents referenced in this plan are retained in the DOE/NV project files in Las Vegas, Nevada, and can be obtained through written request to the DOE/NV Project Manager. This document is available in the DOE public reading rooms located in Las Vegas and Carson City, Nevada, or by contacting the DOE Project Manager. The NDEP maintains the official Administrative Record for all activities conducted under the auspices of the FFACO. 


\subsection{References}

BN, see Bechtel Nevada.

Bechtel Nevada. 1997. Engineering Drawings Index Standard Report. Las Vegas, NV.

CFR, see Code of Federal Regulations.

Code of Federal Regulations. 1996. 40 CFR Part 261, "Identification and Listing of Hazardous Waste." Washington, DC: U.S. Government Printing Office.

DOE, see U.S. Department of Energy.

DOE/NV, see U.S. Department of Energy, Nevada Operations Office.

EG\&G, see Edgerton, Germeshausen, and Grier, Inc.

Edgerton, Germeshausen, and Grier, Inc. 1965. Aerial Photograph of Test Cell A (652-2-21). Las Vegas, NV.

EPA, see U.S. Environmental Protection Agency.

Evenson, G. 1998. Field Trip at Mercury, Nevada to Perform a Radiological Survey and a Site Walkover. Las Vegas, NV: IT Corporation.

FFACO, see Federal Facility Agreement and Consent Order.

Federal Facility Agreement and Consent Order. 1996. Agreed to by the State of Nevada, the U.S. Department of Energy, and the U.S. Department of Defense.

Finney, D. 1998. Bechtel Nevada. Personnel communication to Dave Dahl, IT Corporation, regarding activities at the ETL/TTF, 12 February. Las Vegas, NV: IT Corporation.

Harris, D.L. Undated. Undated, Unlabeled Booklet Regarding the ETL (Building 3124), NRDS, introduction by D. L. Harris. Las Vegas, NV.

IT, see IT Corporation.

IT Corporation. 1998. Mercury Site Visit, April 1998. CAU 266 Preliminary Assessment File. Las Vegas, NV. 
Krieger, H.L., and E.L. Whittaker. 1980. Prescribed Procedures for Measurement of Radioactivity in Drinking Water, EPA-600/4-80-032. Cincinnati, OH: U.S. Environmental Protection Agency.

Miller, M.G. 1984. Nevada Test Site Area 25 Radiological Survey and Cleanup Project 1974 - 1983 , DOE/NV 10327-5, Rev. 1. Las Vegas, NV: Reynolds Electrical \& Engineering Company, Inc.

NAC, see Nevada Administrative Code.

Nevada Administrative Code. 1996. NAC445A.345-445A.22755. "Corrective Action Regulations." Carson City, NV: Nevada Division of Environmental Protection.

Shotten, M. 1998. Bechtel Nevada. Personal communication to Dave Dahl, IT Corporation, regarding activities at the ETL/TTF, 12 February. Las Vegas, NV.

Smucker, S.J. U.S. Environmental Protection Agency. 1998. Memorandum regarding Region 9 Preliminary Remediation Goals (PRGs) 1998. San Francisco, CA.

SNPO, see Space Nuclear Propulsion Office.

Space Nuclear Propulsion Office. 1970. NRDS Master Plan 1969-1970, Nuclear Rocket Development Station, Jackass Flats, Nevada. Las Vegas, NV: U.S. Atomic Energy Commission.

U.S. Department of Energy. 1988a. Environmental Survey Preliminary Report, Nevada Test Site, Nevada, DOE/EH/OEV-15P. Washington, DC: Environment, Safety and Health, Office of Environmental Audit.

U.S. Department of Energy. 1988b. Site Characterization Plan, Yucca Mountain Site, Nevada, DOE/RW - 0199, Vols. I-IX. Las Vegas, NV.

U.S. Department of Energy. 1990. DOE Order 5400.5. "Radiation Protection of the Public and the Environment." Washington, DC: U.S. Government Printing Office.

U.S. Department of Energy, Nevada Operations Office. 1994. Project Management Plan, Rev. 0. Las Vegas, NV.

U.S. Department of Energy, Nevada Operations Office. 1996. Industrial Sites Quality Assurance Project Plan, Nevada Test Site, Nevada, DOE/NV-372. Las Vegas, NV.

U.S. Department of Energy, Nevada Operations Office. 1998a. Environmental Restoration Project Health and Safety Plan, Rev. 3. Las Vegas, NV.

U.S. Department of Energy, Nevada Operations Office. 1998b. Work Plan for Leachfield Corrective Action Units: Nevada Test Site and Tonopah Test Range, Nevada. Las Vegas, NV. 
U.S. Environmental Protection Agency. 1996. Test Methods for Evaluating Solid Waste, Physical/Chemical Methods, SW-846, 3rd Edition, CD ROM. Washington, DC. 


\section{Appendix A}

\section{Data Quality Objectives Worksheets}




\section{A.1.0 Data Quality Objectives Worksheets for the Area 25 Test Cell A Leachfield System (CAU 261)}

\section{A.1.1 Members of the Scoping Team}

\section{A.1.1.1 Scoping Team}

$\mathrm{DOE} / \mathrm{NV}$

Janet Appenzeller-Wing

Clayton Barrow

IT Corp.

Steve Adams

Kenneth Beach

Mark DiStefano

Grant Evenson

Jeanne Wightman
NDEP

Michael McKinnon

Bechtel

Dan Tobiason

Dave Madsen (for Angela Olson)

\section{A.1.1.2 Core Decision Team}

Janet Appenzeller-Wing

Clayton Barrow

Michael McKinnon

Steve Nacht

Kenneth Beach

\section{A.1.1.3 Primary Decision Makers}

Janet Appenzeller-Wing

Clayton Barrow 


\section{A.2.0 Problem Statement}

\section{A.2.1 State the Problem}

Determine whether releases of liquid waste(s) into the leachfield, open drainage feature, and the AWLP has contaminated or has the potential to contaminate underlying soil or groundwater. These releases may have resulted in concentrations in surface and subsurface soils that exceed acceptable regulatory levels; however, insufficient data exists to support a closure decision.

\section{A.2.2 Describe the Site History and List Known or Suspected Sources of Contamination}

Corrective Action Unit 261 consists of two CASs that received wastewaters generated during operations during different periods beginning in 1962 through 1972. The process knowledge and information available for the CAU was compiled during the IT Corporation Preliminary Assessment Team effort. Because of the functional similarities and interconnected routing of wastewaters releasing into the leachfield, the sites can be addressed collectively. The AWLP operated independently as a discharge point for a period of time prior to being connected to the leachfield and an investigation strategy will address this aspect. Selections from the Preliminary Assessment Reports for the CASs were included in the DQO scoping.

\section{A.2.2.1 Descriptions of Processes in Building 3124 That Served as Potential Waste Sources}

Documentation providing evidence for potential contamination was discussed and is included within the CAIP.

\section{A.2.2.2 Analytical Results from Sampling Efforts}

"Radioactivity" data for a leachfield soil sampling effort was provided for the scoping, but was later determined that this may be from another leachfield (see Section 2.5 in main body of document). The information to make the determination is not available. The data will be considered in determining COPCs. 


\section{A.2.3 List Uncertainties and Develop a Preliminary Estimate of Variability}

The list of potential contaminants is based in part on the assumption that the effluent consists of typical acids and bases, degreasing materials, regulated materials and rinsate limited to the known operations during the operational time period. Some of the uncertainties inherent include:

- Quantities - Records of liquid waste quantities discharged through the collection system(s) are not available.

- Physical Form - Most of the operations materials listed in the descriptions are in liquid form. It is not likely that solid wastes were dumped into the drains; it would have been more convenient for workers to dispose of solids in the solid waste system.

- Connectivity/Integrity - The period of time that the drainline was open, if at all, to the ditch at the former outfall prior to extending the line to the leach field is unknown. The physical integrity of the pipeline is also unknown; a possibility exists that there have been minor breaches along the collection system piping.

- Contents - It is unknown if the pipeline, underneath the AWLP, and septic tank (all outside the leachfield) contain any residual materials.

Limited process knowledge and insufficient analytical data is available to adequately estimate the variability for COPCs. 


\section{A.3.0 Develop/Refine the Conceptual Model}

\section{A.3.1 Primary Model}

The primary model describes the most probable scenario for current conditions at the Area 25 Test Cell A Leachfield. Proposed characterization methods are based upon the following assumptions:

- Infiltration and concentration of contaminants in the form of liquid waste into the soil directly below (surrounding) the leachlines and within the leachfield has occurred.

- Minor lateral migration (due to soil anisotropy) of contaminants in the form of liquid waste into the soil exists.

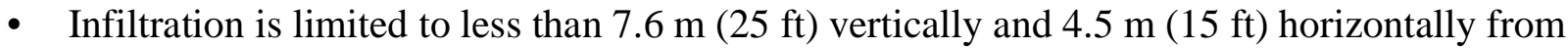
piping, the AWLP, and known leachfield boundaries. Any unknown underground lines extending out of the area could extend the lateral migration pathways further and discovery of this would violate the primary conceptual model.

- Groundwater contamination is unlikely because environmental conditions at the site, such as an arid climate and low permeabilities, are not conducive to downward migration.

- System dynamics are such that there are no driving forces other than limited precipitation and infiltration. Also, fluid inputs through the pipings have not occurred since cessation of operations in 1972.

\section{A.3.2 Alternate Model}

Assumed conditions under the alternate model are considered less likely than assumed conditions under the primary model. Under the following conditions, the alternate model accounts for COPC migration beyond the immediate vicinity:

- Infiltration is greater than $7.6 \mathrm{~m}(25 \mathrm{ft})$ of vertical migration and greater than $4.5 \mathrm{~m}(15 \mathrm{ft})$ of lateral migration.

- If vertical migration is greater than approximately $345 \mathrm{~m}(950 \mathrm{ft})$ (depth to groundwater), then potentially contaminated groundwater could exist.

- Potential soil contamination may exist along collection lines due to loss of integrity in the lines. 


\section{A.4.0 Identify the Decision}

\section{A.4.1 Select the Appropriate Decision for the Current Phase of the Site Assessment Process}

The factors used to select the appropriate decisions include:

- Determine the types and concentrations of contaminants at the site.

- Determine if contaminant concentrations exceed regulatory standards and/or standards for the protection of human health and the environment.

- Determine the extent of contamination with enough certainty to develop and evaluate a range of potential corrective actions for the site, including closure in place and clean closure. 


\section{A.5.0 Identify the Inputs to the Decision}

\section{A.5.1 Identify the Information Inputs Needed to Resolve the Decision and Prepare a List of All of the Data Needed to Resolve the Decision}

\section{A.5.1.1 Contaminant Identification}

The specified parameters for analysis of soils are:

- In and immediately above leachfield - excluding portion unsuitable for sampling (e.g., leachrock, piping, etc.)

- In the septic tank

- In soil below leachfields

- In soil around drain lines (in the event of any identified breaches)

- $\quad$ Residue (possible) inside the piping

- In soil surrounding and inside the AWLP

\section{A.5.1.2 Action Level Exceedence}

Analytical results will be compared to preliminary action levels.

\section{A.5.1.3 Contaminant Migration}

- Boundaries of contaminant migration from indicator parameters and/or analyses of soils for the parameters listed in Section A.5.2

- Soil analysis outside of the leachfield and potential breach areas but within boundaries

- Soil physical characteristics (permeability and geotechnical)

\section{A.5.1.4 Risk Evaluation}

Collect data of sufficient quantity and quality to support a risk evaluation and establishment of risk-based action levels based on Nevada Administrative Code 445A (NAC,1996) and other risk assessment guidance. 


\section{A.5.1.5 Waste Management}

Analytical results sufficient for waste determination and disposal

\section{A.5.2 List Types of Contaminants and Affected Media}

The following is the list of COPCs based on process knowledge:

- VOCs - subsurface soil and surface soil

- SVOCs - subsurface soil and surface soil

- $\quad$ Radionuclides - subsurface soil and surface soil

- Metals - low probability in subsurface soil and surface soil

\section{A.5.3 Identify Potential Sampling Approaches and Appropriate Analytical Methods}

Conduct biased sampling through surface, near-surface sampling, and drilling techniques during the field investigation to confirm or refute the conceptual model for the site, to assess the migration of the COPCs, and to determine if COPCs are present in concentrations exceeding the PALs for the site. Regions exceeding the PALs would necessitate horizontal step-out or deeper borings to investigate any potential migration of subsurface contaminants.

In general, investigate the intervals immediately above and underlying the leachfield and the

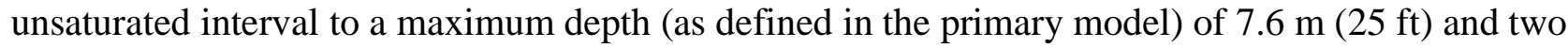
consecutive intervals below appropriate screening levels as determined by field screening and other analytical methods. Representative sampling will consist of the suite listed in A.5.3.1.

In addition, collect samples in order to obtain site-specific geotechnical information applicable to the evaluation of remediation and/or closure options.

\section{A.5.3.1 Appropriate Analytical Methods}

Table 3-1 of the CAIP presents the analytical methods for the COPCs identified during the DQO. Analytical methods for geotechnical analyses are presented in Table 3-2 of the Leachfield Work Plan. 


\section{A.6.0 Define the Boundaries of the Study}

\section{A.6.1 Define the Geographic Areas of the Field Investigation}

Figure 1-2 (in the CAIP) shows a dashed loop demarcating the study area. All contaminated equipment traffic will be within the defined CAU boundaries, with appropriate decontamination taking place prior to exiting boundaries. All IDW will be accumulated within the boundaries of the CAU. The boundary will be of adequate size to contain equipment, spoils, etc. This boundary is subject to change as NTS personnel may be involved in making decisions.

\section{A.6.2 Define the Temporal Boundaries of the Decision}

\section{A.6.2.1 The Time Frame to Which the Study Data Apply Depends on the Following}

- Laboratory hold times for the analytical samples

- Investigation-derived waste sample holding times

- Migration (if occurring) is assumed to be imperceptibly slow, with no wastewater input since cessation of operations and minimal surface water run-on or infiltration.

- The data collection time begins after the CAIP is approved, and allows for finalizing the data and evaluation to support the CADD deadline.

\section{A.6.2.2 Determine When to Collect Data}

Field activities (data collection) are scheduled to take place in November and December 1998. Data will not be collected during electrical storms, holidays, winds, etc.

\section{A.6.2.3 Define Relevant Time Constraints}

The CADD delivery date to the NDEP is July 3, 1999. 


\section{A.6.3 Identify Any Practical Constraints on Data Collection}

Practical constraints on data collection include:

- Administrative restrictions (NTS security constraints)

- Meteorological

- Confined spaces

- Health and safety

- Heavy equipment and resource availability

- Physical access of the site

- Approval of the CAIP 


\section{A.7.0 Develop a Decision Rule - Define a Logical Basis for Choosing Among Alternative Actions}

\section{A.7.1 Specify the Action Level or Preliminary Action Level for the Decision}

Preliminary action levels for the site will be determined based on NAC 445A requirements (NAC, 1996), or 40 Code of Federal Regulations (CFR) 261.24 (as applicable) (CFR, 1996), the toxicity characteristic leaching procedure (TCLP). Instead of directly measuring samples using the TCLP, values will be calculated by dividing the total analytical result by 20 . Additional information to support development of preliminary action levels is available in the Integrated Risk Information System, in the EPA region IX Preliminary Remediation Goals (PRGs) (Smucker, 1998) for industrial sites. The PRGs for radionuclides will be established in accordance with DOE Order 5400.5. Preliminary action levels for radionuclides are concentrations reflecting the average activity of 20 background surface samples plus two times the standard deviation of the average activity. Subsurface soils will be collected from unimpacted area to establish the background levels. The average plus two standard deviations will be used to evaluate site data.

\section{A.7.2 Specify the Variables Acting on the Corrective Action Decisions}

The preferred corrective action alternative will be based on an evaluation of the nature and extent of contamination. Because of the potential for generating a hazardous waste stream during any removal actions which would require treatment or disposal, the economic viability of the removal type alternative is dependent on the volume of contaminated material. If the data collection activities reveal a larger than expected contaminated volume, then a dose-based approach, such as RESRAD, will be considered for the site to evaluate closure in place. 


\section{A.8.0 Specify Acceptable Limits on Decision Errors}

\section{A.8.1 Specify a Range of Possible Parameter Values Where the Consequences of Decision Errors are Relatively Minor}

To reduce the possibility of false positives, biased sampling will be conducted with sampling as close to selected locations (e.g., an established array over known leachfield coordinates, surrounding the AWLP, within the AWLP, at the outfall/drainage feature, at the leachfield distribution box, within the septic tank, and below the septic tank outfall) as possible, yielding the highest confidence that the problem has been found. Statistical sampling is not appropriate for this type of investigation. In lieu of a quantitative determination of sampling error, the false-positive error will be minimized by the following actions. Two consecutive clean samples, confirmed clean through off-site laboratory analysis, will define the lower limit of the affected soils. If unexpected geologic conditions are encountered which affect the contaminant migration pathway (i.e., shallow acquitard), a change to the investigation may be considered.

\section{A.8.2 Assign Probability Values to Points Above and Below the Action Level that Reflect the Acceptable Probability for the Occurrences of Decision Errors}

Because biased sampling is to be performed, assigning confidence level values is not appropriate.

\section{A.8.3 Check for Consistency - Check the Limits on Decision Errors to Ensure that They Accurately Reflect the Decision Maker's Concerns About the Relative Consequences for Each Type of Decision Error}

Although qualitative in approach, the sampling is designed to minimize concerns for false positives. 


\section{A.9.0 Optimize the Design - Outline a Sampling Design, Specifying the Operational Details of the Sampling Plan Which Falls Within the Project's Constraints}

\section{A.9.1 Develop General Sampling and Analysis Design Alternatives}

\section{A.9.1.1 Develop a Preliminary Estimate of Variability}

Insufficient data is available to adequately estimate the variability for the likely constituents of concern.

\section{A.9.1.2 Develop a Sampling Strategy for the Site that Specifies All of the Previous/y Defined Data Quality Objectives}

The sampling strategy is:

- Sampling below the outfall end of the septic tank, collecting grab samples at the outfall/ditch, collecting samples inside the AWLP, sampling the contents of the tank, and collecting grab samples at identified breaches along the piping. These breaches may be identified with a pipeline video camera (mole) that can be introduced through the piping. A radiological screening instrument may be coupled with the camera in order to characterize the pipe in place.

- Subsurface drilling (i.e., less than $7.6 \mathrm{~m}[25 \mathrm{ft}] \mathrm{bgs}$, as defined by the conceptual model) and sampling to confirm or refute contamination at greater depths immediately below the above locations, as needed. Drilling an array of boreholes at field-established coordinates (based on engineering drawings) of the leachfield. Also, drill and collect samples near the AWLP.

\section{A.9.2 Select the Most Resource-Effective Design that Satisfies All of the DQOs}

Conduct biased sampling during the field investigation to confirm or refute the conceptual model for the site, to assess the migration of the COPCs, and to determine if COPCs are present in concentrations exceeding the PALs for the site. Select sampling points within the leachfield, at the outfall end of the septic tank, and concentrated around the distribution box, as sampling locations. Locate and target soil surrounding piping showing obvious breaches, leakages, and loss of system integrity. At both the proximal and distal ends of the leachfield(s), overlay a sampling pattern on the leachlines and collect subsurface soil samples at various depths below the distribution lines, and at one interval immediately above the installed leachfield materials. Collect soil samples with a drill rig 
as needed to track the vertical extent of contamination. Regions exceeding the PALs would necessitate horizontal step-out or deeper borings to investigate any potential migration of subsurface contaminants.

In general, investigate the contents of the leachfields and the unsaturated interval to a maximum depth (as defined in the primary model) of $7.6 \mathrm{~m}(25 \mathrm{ft})$ and two consecutive intervals below appropriate screening levels as determined by field screening and other analytical methods.

In addition, collect samples in order to obtain site-specific geotechnical information applicable to the evaluation of remediation and/or closure options. 


\section{Appendix B}

\section{Existing Water \& Sewer Layout Test Cell "A" Plan}




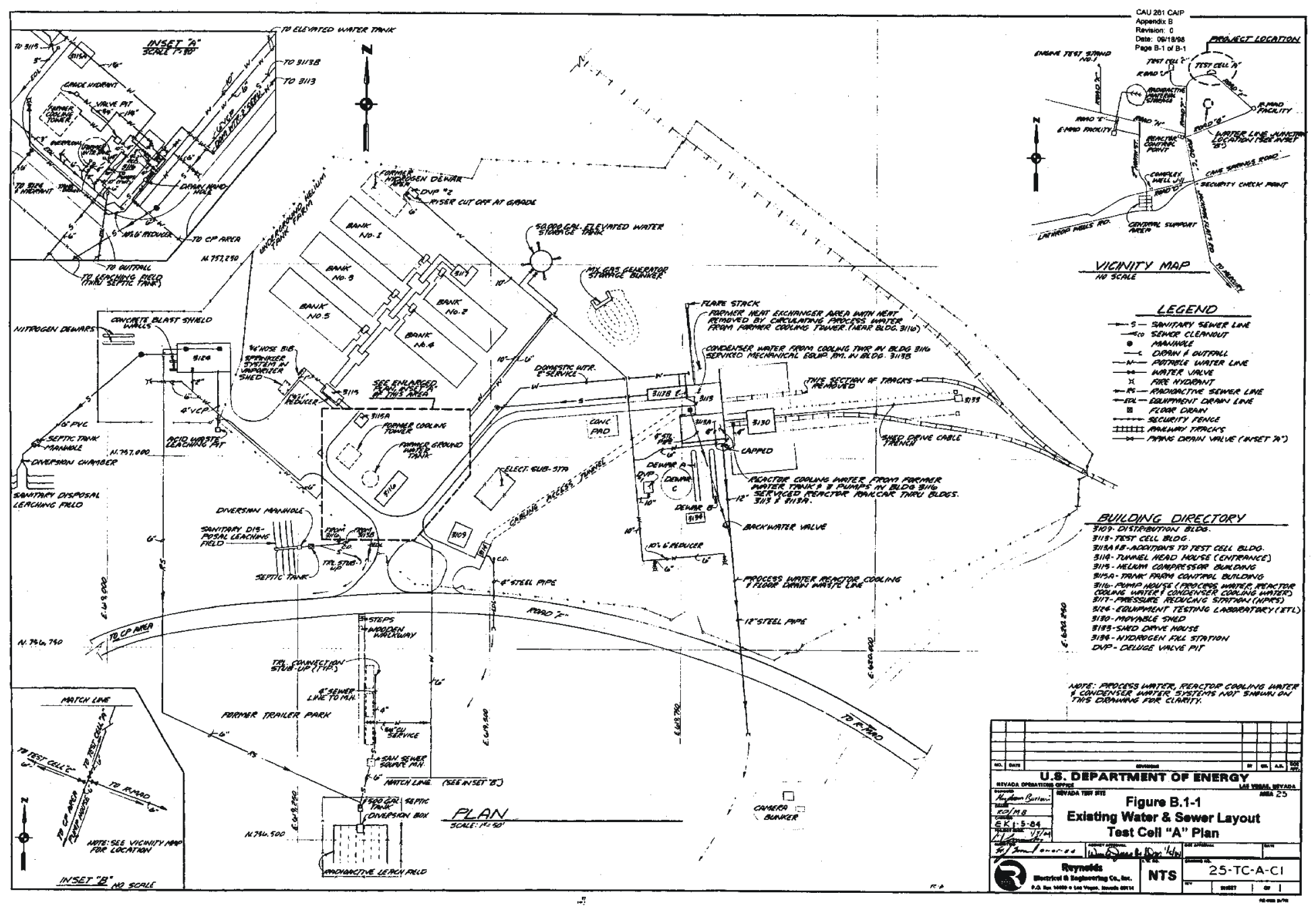


Appendix C

Document Review Sheet 


\section{NEVADA ENVIRONMENTAL RESTORATION PROJECT DOCUMENT REVIEW SHEET}

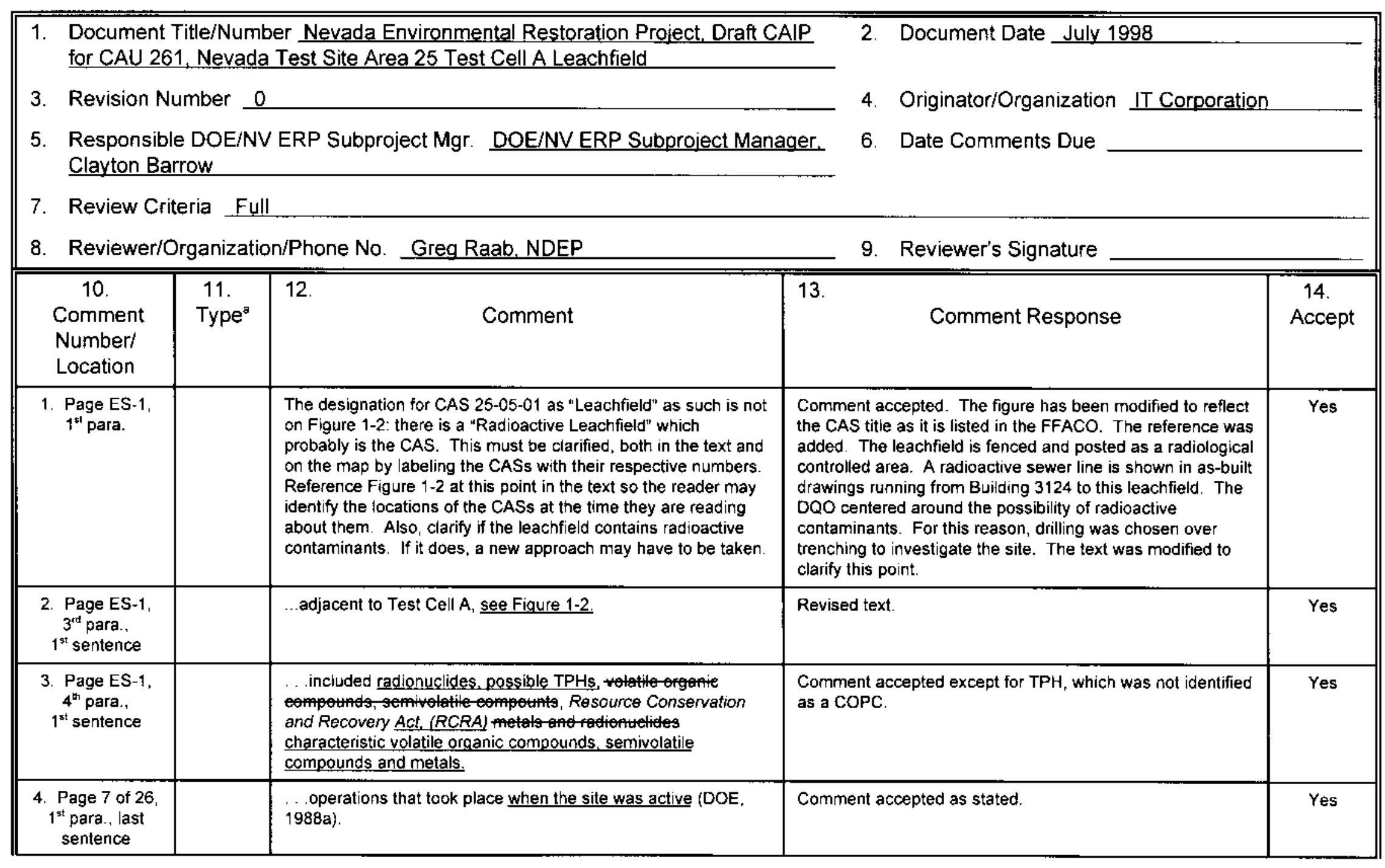




\section{NEVADA ENVIRONMENTAL RESTORATION PROJECT DOCUMENT REVIEW SHEET}

Document Title/Number Nevada Environmental Restoration Project. Draft CAIP for CAU

Revision Number 261. Nevada Test Site Area 25 Test Cell A Leachfield

Reviewer/Organization DOE/NV ERP Subproject Manager. Clayton Barrow

\begin{tabular}{|c|c|c|c|c|}
\hline $\begin{array}{l}10 . \\
\text { Comment } \\
\text { Number/ } \\
\text { Location }\end{array}$ & $\begin{array}{l}11 . \\
\text { Type }^{\text {a }}\end{array}$ & Comment & Comment Response & $\begin{array}{c}14 \\
\text { Accept }\end{array}$ \\
\hline $\begin{array}{l}\text { 5. Page } 11 \text { of } \\
26, \text { Section } 3.3 \\
\text { Preliminary } \\
\text { Action Levels }\end{array}$ & & $\begin{array}{l}\text { Screening levels for on-site field screening methods. . . There } \\
\text { are no methods of Standard Operating Procedures (SOPs) } \\
\text { referenced anywhere for the field-portable instruments. If the } \\
\text { quality of data is to be established, there must be both } \\
\text { procedures and documentation to verify and validate the } \\
\text { analytical data.] }\end{array}$ & $\begin{array}{l}\text { Field instruments are calibrated and operated to } \\
\text { manufacturer's specifications. All field screening data is } \\
\text { Category I to be used as a qualitative estimate of the limits } \\
\text { of contamination. Field screening data are supported by } \\
\text { laboratory analysis. The decisions on corrective action are } \\
\text { based on laboratory analysis, not field screening. Samples } \\
\text { for laboratory analysis are collected and analyzed as } \\
\text { specified in the CAIP, including data collection decision } \\
\text { points and sampling intervals. The field screening data are } \\
\text { used to guide the investigation. If laboratory data do not } \\
\text { substantiate the field screening data, additional investigation } \\
\text { activities would be considered. This information has been } \\
\text { incorporated into the work plan. The CAIP references the } \\
\text { work plan. }\end{array}$ & In part \\
\hline $\begin{array}{l}\text { 6. Page } 10, \\
1^{\text {tt }} \text { para., } \\
1^{\text {st }} \text { sentence }\end{array}$ & & $\begin{array}{l}\text { The indication here is that } 8,800 \mathrm{~L} \text { of "contaminated water" may } \\
\text { well have been discharged to the leachfield. Under Section } \\
2.2 .3 \text {, first paragraph, third sentence states"... process } \\
\text { knowledge indicates that this was a likely use. If this is true, } \\
\text { and it was radioactive, the soil may be contaminated above the } \\
\text { PALs. Are there contingency plans other than the borehole } \\
\text { placement and sample collection described in Section } 4.3 \\
\text { referencing the leachfield work plan? Describe how excessive } \\
\text { radiologically contaminated soils will be handled and the level of } \\
\text { worker safety at the site required for such levels. I }\end{array}$ & $\begin{array}{l}\text { See response to Comment } 1 \text {. The site is potentially } \\
\text { radiologically contarninated. The health and safety } \\
\text { requirements and procedures will be specified in the } \\
\text { SSHASP. Drilling was chosen to limit generation of } \\
\text { contaminated soils and minimize potential personnel } \\
\text { exposure. Radiologically contaminated soils will be handled } \\
\text { according to the waste management protocols described in } \\
\text { Section } 5.0 \text { of the work plan and Section } 5.0 \text { of the CAIP. } \\
\text { and in conformance with applicable DOE Orders and } \\
\text { regulations and the NTSWAC. }\end{array}$ & No \\
\hline $\begin{array}{l}\text { 7. Page } 11 \text { of } \\
26 \text {, Section } 3.3, \\
4^{\text {st }} \text { para. } \\
1^{\text {st }} \text { bullet }\end{array}$ & & $\begin{array}{l}\text { [How does the } 20 \mathrm{ppm} \text { in the headspace relate to concentration } \\
\text { in the soil? How and where is the background measured? If } \\
\text { there were listed wastes involved, this may not suffice.] }\end{array}$ & $\begin{array}{l}\text { The } 20 \mathrm{ppm} \text { is a relational value based on historical field } \\
\text { screening and laboratory results. The field screening data } \\
\text { do not represent absolute decision points because they are } \\
\text { verified by laboratory data. Confirmatory samples will be } \\
\text { collected from every boring as stated in the work plan and } \\
\text { the CAIP. }\end{array}$ & No \\
\hline
\end{tabular}




\section{NEVADA ENVIRONMENTAL RESTORATION PROJECT DOCUMENT REVIEW SHEET}

Document Title/Number Nevada Environmental Restoration Project. Draft CAIP for CAU

Revision Number 0 261. Nevada Test Site Area 25 Test Cell A Leąchfield

Reviewer/Organization DOE/NV ERP Subproject Manager. Clayton Barrow

\begin{tabular}{|c|c|c|c|c|}
\hline $\begin{array}{l}10 . \\
\text { Comment } \\
\text { Number/ } \\
\text { Location }\end{array}$ & $\begin{array}{l}11 . \\
\text { Type }^{a}\end{array}$ & Comment & Comment Response & $\begin{array}{l}14 . \\
\text { Accept }\end{array}$ \\
\hline $\begin{array}{l}\text { 8. Page } 11 \text { of } \\
\text { 26. Section } 3.3 \text {, } \\
1^{\text {st }} \text { para. } \\
2^{\text {nd }} \text { bullet }\end{array}$ & & $\begin{array}{l}\text { Radiation (alpha, beta/gamma) screening leveis } 2.5 \text { times } \\
\text { greater than an area background... [How is this going to be } \\
\text { done? Why specifically } 2.5 \text { times? Define what area } \\
\text { background is? Please explain in detail. An example of the } \\
\text { kind of details NDEP needs can be found in Roller Coaster Rad } \\
\text { Safe Area CAIP.] }\end{array}$ & $\begin{array}{l}\text { Comment accepted. The text in the work plan was revised } \\
\text { to reflect the procedure in the Roller Coaster CAIP. The } \\
\text { CAIP references the work plan. }\end{array}$ & Yes \\
\hline $\begin{array}{l}\text { 9. Page } 12 \text { of } \\
26 \text {, Section } 3.4\end{array}$ & & $\begin{array}{l}\text { [Insert before last sentence:] Data packages from off-site } \\
\text { laboratories will be reviewed by staff to verify the quality of data } \\
\text { at a tier II level as described in the Industrial Sites Quality } \\
\text { Assurance Project Plan, Section } 6.5 .2 .2 \text {. Any deficiencies noted } \\
\text { by the laboratory manager must be checked to verify the } \\
\text { analytical results fall within the established QAVC DQO sor the } \\
\text { site. Any deviations must be noted and evaluated for re- } \\
\text { analysis. [This should be added as well to the leachfield } \\
\text { workplan on p. } 9 \text { of } 30, \text { preceding the first sentence on the } \\
\text { page.] }\end{array}$ & $\begin{array}{l}\text { Comment accepted; changes were made to the work plan. } \\
\text { The CAIP references the work plan. }\end{array}$ & Yes \\
\hline $\begin{array}{l}\text { 10. Page } 14 \text { of } \\
26, \text { Section } \\
4.2 .1, \text { last } \\
\text { sentence }\end{array}$ & & $\begin{array}{l}\text { [If there are indications in the records or suspected other } \\
\text { sources of contaminants, it would be prudent to spend the time } \\
\text { to identify them now rather than later. If there are sources found } \\
\text { and the inclusion in CAIP } 261 \text { would impact the time lines, } \\
\text { NDEP needs to be notified as soon as possible.] }\end{array}$ & $\begin{array}{l}\text { All available records to date have been reviewed and } \\
\text { incorporated into this document. If additional information is } \\
\text { uncovered, the information will be evaluated and forwarded } \\
\text { to NDEP. }\end{array}$ & \\
\hline
\end{tabular}




\section{NEVADA ENVIRONMENTAL RESTORATION PROJECT DOCUMENT REVIEW SHEET}

Document Title/Number Nevada Environmental Restoration Project. Draft CAIP for CAU

Revision Number $\underline{0}$ 261. Nevada Test Site Area 25 Test Cell A Leachfield

Reviewer/Organization DOE/NV ERP Subproject Manager. Clayton Barrow

\begin{tabular}{|c|c|c|c|c|}
\hline $\begin{array}{l}10 \\
\text { Comment } \\
\text { Number/ } \\
\text { Location }\end{array}$ & $\begin{array}{l}11 \\
\text { Type }\end{array}$ & 12 & Comment Response & $\begin{array}{c}14 . \\
\text { Accept }\end{array}$ \\
\hline $\begin{array}{l}\text { 11. Page } 14 \text { of } \\
26 \text {, Section } 4.2 .2\end{array}$ & & $\begin{array}{l}\text { Field Screening methodology is discussed in the Section } 4.2 .4 \\
\text { of the leachfieid work plan. [In Section } 4.2 .4 \text { of the leachfield } \\
\text { work plan, there are no references to whether the data will be } \\
\text { Category I, II, or III as described in the Industrial Sites QAPP, } \\
\text { (DOE/NV, 1996). Regardless of category, there are no } \\
\text { references to or descriptions of methods or standard operating } \\
\text { procedures for field analytical instrumentation of any sort. This } \\
\text { is substantially deficient and must be corrected. All screening } \\
\text { data described in this CAIP are the basis for the initial decisions } \\
\text { made at the site and for everything in the project. Without } \\
\text { proper QAVQC procedures and documentation, any subsequent } \\
\text { analytical results could be invalidated. The radiological } \\
\text { screening instruments are especially important. Even though } \\
\text { they are somewhat simplistic in application, there must be some } \\
\text { sort of QC documentation of process and procedure concerning } \\
\text { calibration, sensor response, condition of the sensor cover, } \\
\text { battery check, decontamination procedures, etc. Any qualifying } \\
\text { parameters must be in the SOPS or methods, and their QAOCC } \\
\text { parameters (PARCCs) must be incorporated into the DQO } \\
\text { decision making and reference tables.] }\end{array}$ & See response to Comment 5 . & \\
\hline $\begin{array}{l}\text { 12. Page } 14 \\
\text { of } 26 \text {, } \\
3^{r d} \text { paragraph, } \\
7^{\text {th }} \text { sentence }\end{array}$ & & $\begin{array}{l}\text { Additionally, a decision was reached while developing in the } \\
\text { DQO's to define... }\end{array}$ & Comment accepted. & Yes \\
\hline $\begin{array}{l}\text { 13. Page } 19 \text { of } \\
26,2^{\text {2n }} \text { para.. } \\
\text { last sentence }\end{array}$ & & $\begin{array}{l}\text { If drilling to depths past the limits of the rig is necessary, the } \\
\text { project... }\end{array}$ & Comment accepted. & Yes \\
\hline $\begin{array}{l}\text { 14. Appendix A, } \\
\text { page A-2, } \\
\text { Section A.2.2.2, } \\
\text { last sentence on } \\
\text { page }\end{array}$ & & $\begin{array}{l}\text {. but was later determined that this is that of another } \\
\text { leachfield. [Either it is or it is not. State which it is.] }\end{array}$ & $\begin{array}{l}\text { Comment accepted in part. The sentence was changed as } \\
\text { stated. However, uncertainty remains in the available } \\
\text { information. Therefore, we are assuming that the } \\
\text { contaminants identified in the report could be found at the } \\
\text { CAU. }\end{array}$ & Yes \\
\hline
\end{tabular}




\section{NEVADA ENVIRONMENTAL RESTORATION PROJECT DOCUMENT REVIEW SHEET}

Document Title/Number Nevada Environmental Restoration Project. Draft CAIP for CAU

Revision Number 0

\section{Nevada Test Site Area 25 Test Cell A Leachfield}

Reviewer/Organization DOE/NV ERP Subproject Manager, Clayton Barrow

\begin{tabular}{|c|c|c|c|c|}
\hline $\begin{array}{l}10 \text {. } \\
\text { Comment } \\
\text { Number/ } \\
\text { Location }\end{array}$ & $\begin{array}{c}11 . \\
\text { Type }\end{array}$ & Comment & Comment Response & $\begin{array}{c}14 . \\
\text { Accept }\end{array}$ \\
\hline $\begin{array}{l}\text { 15. Appendix A, } \\
\text { page A-8, } \\
\text { Section A.5.3.1 }\end{array}$ & & $\begin{array}{l}\text { [The parameters selected by the Scoping Team should be } \\
\text { detailed here. What process knowledge and requirements were } \\
\text { there to select the methods, or if it is already described, } \\
\text { reference it here. Also add the reference to Table } 3-1 \text { as the } \\
\text { conclusion to the development of Data Quality Objectives.] }\end{array}$ & $\begin{array}{l}\text { Comment accepted. The referenced text was replaced in } \\
\text { revisions to the document. }\end{array}$ & Yes \\
\hline $\begin{array}{l}\text { 16. Appendix } A \\
\text { page A-11. } \\
\text { Section A. } 7.1 \\
1^{\text {st }} \text { para. } \\
5^{\text {th }} \text { sentence }\end{array}$ & & $\begin{array}{l}\text { Preliminary action levels for radionuclides are concentrations } \\
\text { greater than twice an established background level. [As noted } \\
\text { above, DOE must provide NDEP with the kind of detail found in } \\
\text { Roller Coaster Rad Safe Area CAIP.] }\end{array}$ & Comment accepted. See response to Comment 8 . & Yes \\
\hline $\begin{array}{l}\text { 17. Appendix A, } \\
\text { page A-12, } \\
\text { Section A.8.1, } \\
1^{\text {st }} \text { para., } \\
1^{\text {st }} \text { sentence }\end{array}$ & & $\begin{array}{l}\text { To reduce the possibility of false positives, biased sampling } \\
\text { will ... }\end{array}$ & Comment accepted as stated. & Yes \\
\hline $\begin{array}{l}\text { 18. Appendix A, } \\
\text { page A-12, } \\
\text { Section A.8.2, } \\
1^{\text {st para, }} \\
1^{\text {st }} \text { sentence }\end{array}$ & & Because biased sampling is . & Comment accepted as stated. & Yes \\
\hline
\end{tabular}

acomment Types: $M=$ Mandatory, $S=$ Suggested. (Were not provided by reviewer)

Return Document Review Sheets to DOE/NV Environmental Restoration Division, Attn: QAC, M/S 505.

Note: Underlined portions (found in comment section) are the desired inserts or additions. 


\section{Distribution}

*Distribute only if Rev. 0 is approved without changes. If Rev. 1 is issued, distribute to entire list.

$\underline{\text { Copies }}$

Paul J. Liebendorfer

2 (Controlled)

State of Nevada

Bureau of Federal Facilities

Division of Environmental Protection

333 W. Nye Lane, Room 138

Carson City, NV 89706-0851

Supervisor

1 (Controlled)

State of Nevada

Bureau of Federal Facilities

Division of Environmental Protection

555 E. Washington, Suite 4300

Las Vegas, NV 89101

Sabrina Lawrence

1 (Controlled)

Environmental Restoration Division

DOE/Nevada Operations Office

P.O. Box 98518, M/S 505

Las Vegas, NV 89193-8518

Janet Appenzeller-Wing

1 (Uncontrolled)

Environmental Restoration Division

DOE/Nevada Operations Office

P.O. Box 98518, M/S 505

Las Vegas, NV 89193-8518

Clayton Barrow

1 (Uncontrolled)

Environmental Restoration Division

DOE/Nevada Operations Office

P.O. Box 98518, M/S 505

Las Vegas, NV 89193-8518

Angela Olson

1 (Uncontrolled)

Bechtel Nevada

P.O. Box 98521, M/S NTS306

Las Vegas, NV 89193-8521 
Steve Nacht

Bechtel Nevada

P.O. Box 98521, M/S NTS306

Las Vegas, NV 89193-8521

Mark DiStefano

IT Corporation

P.O. Box 93838

Las Vegas, NV 89193

Jason Moore

SAIC

P.O. Box 93838

Las Vegas, NV 89193

Mary Todd

SAIC

P.O. Box 93838

Las Vegas, NV 89193

Dustin Wilson

SAIC

P.O. Box 93838

Las Vegas, NV 89193

IT Corporation Central Files

IT Corporation

P.O. Box 93838

Las Vegas, NV 89193

Technical Information Resource Center

DOE/Nevada Operations Office

P.O. Box 98518, M/S 505

Las Vegas, NV 89193-8518

U.S. Department of Energy

Office of Scientific and Technical Information

P.O. Box 62

Oak Ridge, TN 37831

DOE Public Reading Room

P.O. Box 98521, M/S NLV040

Las Vegas, NV 89193-8521
1 (Uncontrolled)

1 (Uncontrolled)

1 (Controlled)

1 (Uncontrolled)

1 (Uncontrolled)

1 (Uncontrolled)

1 (Uncontrolled)*

1 (Uncontrolled, electronic copy)*

1 (Controlled)*

1 (Uncontrolled)* 
Rosa Silver

IT Corporation

P.O. Box 93838

Las Vegas, NV 89193
1 (Controlled)*

1 (Uncontrolled)* 